NBER WORKING PAPER SERIES

\title{
THE HIDDEN BENEFITS OF CONTROL: EVIDENCE FROM A NATURAL FIELD EXPERIMENT
}

\author{
Craig E. Landry \\ Andreas Lange \\ John A. List \\ Michael K. Price \\ Nicholas G. Rupp \\ Working Paper 17473 \\ http://www.nber.org/papers/w17473 \\ NATIONAL BUREAU OF ECONOMIC RESEARCH \\ 1050 Massachusetts Avenue \\ Cambridge, MA 02138 \\ September 2011
}

We are grateful to Jamie Brown-Kruse for working with us in her capacity as the Director of the Hazards Center. We thank Glenn Harrison, and Lise Vesterlund for excellent insights that markedly improved the study. Seminar participants at Harvard University, the University of Chicago, MIT, the University of Nevada, Reno, the 2006 North American meetings of the Economic Science Association, the 2007 meetings of the Allied Social Science Associations, and the Princeton Charitable Fundraising Conference in July 2007 also provided useful insights. The views expressed herein are those of the authors and do not necessarily reflect the views of the National Bureau of Economic Research.

NBER working papers are circulated for discussion and comment purposes. They have not been peerreviewed or been subject to the review by the NBER Board of Directors that accompanies official NBER publications.

(C) 2011 by Craig E. Landry, Andreas Lange, John A. List, Michael K. Price, and Nicholas G. Rupp. All rights reserved. Short sections of text, not to exceed two paragraphs, may be quoted without explicit permission provided that full credit, including $\odot$ notice, is given to the source. 
The Hidden Benefits of Control: Evidence from a Natural Field Experiment

Craig E. Landry, Andreas Lange, John A. List, Michael K. Price, and Nicholas G. Rupp

NBER Working Paper No. 17473

September 2011

JEL No. C93,D03,H41,Q5

\begin{abstract}
$\underline{\text { ABSTRACT }}$
An important dialogue between theorists and experimentalists over the past few decades has raised the study of the interaction of psychological and economic incentives from academic curiosity to a bona fide academic field. One recent area of study within this genre that has sparked interest and debate revolves around the "hidden costs" of conditional incentives. This study overlays randomization on a naturally-occurring environment in a series of temporally-linked field experiments to advance our understanding of the economics of charity and test if such "costs" exist in the field. This approach permits us to examine why people initially give to charities, and what factors keep them committed to the cause. Several key findings emerge. First, there are hidden benefits of conditional incentives that would have gone undetected had we maintained a static theory and an experimental design that focused on short run substitution effects rather than dynamic interactions. Second, we can reject the pure altruism model of giving. Third, we find that public good provision is maximized in both the short and long run by using conditional, rather than unconditional, incentives.
\end{abstract}

\author{
Craig E. Landry \\ East Carolina University \\ landryc@ecu.edu \\ Andreas Lange \\ University of Hamburg \\ Department of Economics \\ Von Melle Park 5 \\ 20146 Hamburg \\ Germany \\ andreas.lange@wiso.uni-hamburg.de \\ John A. List \\ Department of Economics \\ University of Chicago \\ 1126 East 59th \\ Chicago, IL 60637 \\ and NBER \\ jlist@uchicago.edu
}

Michael K. Price

Department of Economics

University of Tennessee

515 Stokely Management Center

Knoxville, TN 27996

and NBER

mprice21@utk.edu

Nicholas G. Rupp

East Carolina University

ruppn@ecu.edu 


\section{Introduction}

According to Greek mythology, mankind's first philanthropist was the Titan, Prometheus, who gave fire to mortal man. Since Prometheus' initial act of charity, providing assistance to others has become a cornerstone of many cultures and belief systems. ${ }^{1}$ Despite the historical link with religious activity or duty, the role of charitable fund-raising and the number of organizations involved in such activities has been expanding rapidly. ${ }^{2}$ In the United States alone, there are now more than 1.5 million registered non-profit organizations and nearly 90 percent of all American families contribute to charity.

While fund-raisers have developed a variety of strategies to achieve specific funding targets, such strategies frequently rely upon rules of thumb rather than hard scientific evidence on what induces donors to give. For example, a popular belief amongst fund-raisers is that potential donors are more generous when gifts are included with solicitation requests. While there is ample empirical evidence that unconditional gifts enhance fund-raising success (see, e.g., Alpizar et al. 2008; Edlund et al. 2007; Falk 2007; Regan 1971; Whatley et al. 1999), there are numerous other ways charities organize gift exchange in field settings - i.e., making gifts conditional and varying the minimum donation required to obtain such gifts.

Viewed through the lens of behavioral economics, the use of conditional gifts is a puzzle. Within the context of principal-agent games, such incentives have been shown to influence behavioral in an unexpected manner - the use of explicit threats to sanction shirking backfires

\footnotetext{
${ }^{1}$ For example, the concept of giving (zakat) is among five duties incumbent upon every Muslim. Similar notions of giving are fundamental to other religions such as Judaism (tsedakah), Buddhism (dana), and Christianity (tithing) and appear as central themes in writings such as Cicero's On Moral Obligations or Alexander Pope's “An Essay on Man" that cross generations and cultures.

${ }^{2}$ Starting in the mid-1800s, non-profit organizations introduced fund-raising techniques that targeted individual donors for financial assistance. Perhaps spurred by the desires of entrepreneurs such as Andrew Carnegie, Edsel Ford, and John D. Rockefeller, many of these approaches were designed to assure donors that their funds would be used to further the development of deserving individuals. For a more detailed history of charity and philanthropy, we refer the interested reader to Giving: Charity and Philanthropy in History, by Robert H. Bremmer.
} 
and serves to crowd out motivation (see, e.g., Falk and Kosfeld, 2006; Fehr and List, 2004; Fehr and Rockenbach, 2003; Sliwka, 2007). Accordingly, the use of conditional incentives (control) entails "hidden" costs that escape our attention if reasoning is based on models that assume individuals are exclusively self-interested (Fehr and List, 2004). Despite this evidence, whether and how reciprocity and control influence charitable donations is an important open issue.

In this study, we present an empirical approach that is composed of a set of field treatments that parallel the important economic features of the environments in previous studies examining the costs of control. To do so, we organize a series of capital campaigns for the Center for Natural Hazards Research at East Carolina University. Importantly, we use natural incentives to change exogenously the solicitees' action space. ${ }^{3}$ In one set of treatments, solicitees are provided an unconditional small or large gift. In another set of treatments, the most opportunistic actions are ruled out by making the gifts conditional-i.e., the solicitee must contribute a positive dollar amount to obtain the small or large gift. The final set of treatments restricts the choice set even further by enforcing greater control over the donor-the donor receives the small (large) gift only if she contributes at least to the level of a certain price point (\$1 (\$25)), the approximate retail value of the gift. In this way, if solicitor trust is a characteristic rewarded by solicitees, then the control evoked in the final set of treatments via introduction of the price point might crowd out donations.

We observe several interesting data patterns. First, unconditional gifts enhance fundraising success. Relative to individuals approached in the baseline treatment, solicitees approached in our unconditional large gift treatment are nearly twice as likely to contribute (36.8\% versus $21.3 \%$ ) and, on average, donate more than twice as much ( $\$ 4.48$ versus $\$ 1.90)$ to

\footnotetext{
${ }^{3}$ In this regard, our work shares similarity with Landry et al. (2011) who explore the effect of conditional and unconditional gifts on the productivity of solicitors raising money for the Hazard Center.
} 
the Hazard Center. Second, both average contributions per contact and participation rates are reduced when we introduce conditionality. For example, average contributions in our no price point treatment are approximately fifty percent lower than those observed in our unconditional large gift treatment. Moreover, both rates of giving and average donations per contact are decreasing in the contribution level (price point) required to obtain the large gift. These results are consonant with our theoretical model.

Third, we observe an increased propensity for donors in our conditional gift treatments to pool at the minimum contribution level required to obtain the gift. Whereas 2.04 percent of all households approached contribute $\$ 1.00$ in our unconditional small gift treatment, the percentage of households that contribute this amount in the corresponding price point treatment increases nearly six-fold. We observe similar data patterns in our large gift treatments - the percentage of households contributing \$25 nearly triples when we move from the unconditional to the price point treatment.

Finally, net public good provision per household - average contributions less the costs of purchasing the gifts - is increasing in the price point. In fact, gross proceeds in both the unconditional and no price point large gift treatments were insufficient to cover our costs of purchasing the large gift. Net revenues per contact in these treatments are thus significantly lower than that observed in both the baseline and price point large gift treatments. Hence, our data suggest that in the short-run a charity is better off providing gifts conditionally to screen non-reciprocal types for whom gift exchange is a net loser.

However, as conditional gifts serve to crowd out donors, it is not clear whether conditionality is an optimal long-run strategy. Since households in our unconditional large gift treatment were approximately 74.4 percent more likely to give than counterparts approached in 
the corresponding price point treatment, it is plausible that unconditional gifts enhance profitability in the long-run. To better ascertain long-run impacts, we returned to the field and implemented a second door-to-door fund-raising experiment.

In designing the second field experiment, we made use of detailed information on whether and how households were previously approached. Two distinct household types - (i) those who contributed in experiment I (warm-list households) and (ii) those who have never contributed to the Hazard Center (cold-list households) - were randomly approached and asked to contribute using a simple ask strategy. As small gifts had no discernable impact on outcomes in experiment I, we restrict the sample of warm-list households to those previously approached in either the baseline or one of the three large-gift treatments.

Results from the second experiment highlight two main findings. First, feelings of reciprocity - as triggered by the receipt of an unconditional gift - wane over time. Households initially attracted by an unconditional gift are approximately 60.2 percent less likely to contribute in our follow-up experiment and provide average gifts that are approximately 63 percent lower than counterparts initially attracted by a conditional gift. This suggests that the conditionality served as an effective screen of those who were truly interested in giving to our charity. Second, households initially attracted via a conditional gift are significantly more likely to contribute and provide larger average gifts than counterparts who initially gave in the baseline. Taken jointly, our data therefore suggest that conditional gift exchange proves a superior fund-raising strategy in both the short- and the long-run. ${ }^{4}$

Our results therefore can be interpreted as speaking to several distinct literatures. For the reciprocity literature, our results suggest that gift exchange is important, but that it is limited to

\footnotetext{
${ }^{4}$ This result is consonant with Landry et al. (2011) who find that the use of conditional rewards to incent solicitors is a profit enhancing wage structure.
} 
the immediate source of kindness; that is, all effects of gift exchange are contemporaneous. Speaking to the fundraising literature, we can reject the pure altruism model and instead find evidence in favor of the signaling and warm glow models (Vesterlund, 2003; Andreoni, 2006; List and Lucking-Reiley, 2002). Further, our results shed light on the puzzle of why some charities use conditional gifts whereas others choose unconditional gifts. For behavioral economics, we find new evidence of the hidden benefits of control: whereas the benefits arise because conditionality is an effective technology to screen donors, such effects would have been missed had we followed the standard approach of using a static model and an experimental design that focused on measuring short run substitution effects.

\section{Theoretical Model}

We provide a simple model to focus our attention on the most important determinants of giving. Our framework augments Andreoni's $(1989,1990)$ impure altruism model to allow for reciprocal preferences over gifts provided either conditionally or unconditionally. We consider an agent $i \in \Omega$ who receives utility from consuming a numeraire good, $y_{i}$, a public good provided at level $G$, and (possibly) from their contribution to the public good $b$. Receiving a gift generates some consumption utility, $v_{i}(g)$, where $g$ measures the perceived cost of the gift to the charity and $v_{i}(0)=0$. Receiving a gift may also trigger reciprocity captured by an additional utility component, $r_{i}\left(b_{i}, \mu g\right)$. Feelings of reciprocity are assumed to depend both on the consumption value of the gift and its perceived generosity - represented by a parameter $\mu \in[0,1] .{ }^{5}$ Throughout, we assume that $\mu=1$ for a gift provided unconditionally and that $\mu$ is

\footnotetext{
5 That is, if the gift is provided conditionally - i.e., linked to some minimum contribution level - rather than unconditionally, the perceived generosity is reduced. Intuitively, this assumption captures the hidden costs of control noted in the earlier literature (Falk and Kosfeld, 2006; Sliwka, 2007).
} 
reduced if the gift is conditional on specific requirements.

Assuming that utility is additively separable in these different components, agent $i$ 's utility facing a budget constraint $y_{i}+b_{i} \leq w_{i}$ and receiving a gift $g$ with conditionality factor $\mu$ is defined as:

$$
U_{i}\left(b_{i}, g, \mu\right)=w_{i}-b_{i}+v_{i}(g)+h_{i}\left(b_{i}+B_{-i}\right)+f_{i}\left(b_{i}\right)+r_{i}\left(b_{i}, \mu g\right)
$$

where $B_{-i}=\sum_{j \neq i} b_{j}$. We assume that $h_{i}(\bullet), f_{i}(\bullet)$, and $r_{i}(\bullet)$ are each increasing and concave in $b$. Finally, for a given donation size, we assume that marginal benefit from reciprocity is decreasing in gift size - i.e., $\frac{\partial r_{i}}{\partial g} \leq 0$, while the marginal utility from giving is increasing in gift size $\frac{\partial^{2} r_{i}}{\partial b \partial g} \geq 0$. As solicitees in many naturally-occuring settings are able to refuse an offered gift, we define an indicator variable as $a_{i}=1$ if agent $i$ "accepts" the gift and $a_{i}=0$ if the agent instead "refuses" the gift. ${ }^{6}$ For simplicity, we thus specify the donor's utility function as,

$$
U_{i}\left(b_{i}, a_{i}, g, \mu\right)=w_{i}-b_{i}+a_{i} v_{i}(g)+h_{i}\left(b_{i}+B_{-i}\right)+f_{i}\left(b_{i}\right)+r_{i}\left(b_{i}, a_{i} \mu g\right)
$$

i.e., we assume that rejecting and not receiving a gift are viewed by the donor as equivalent outcomes.

The agent maximizes (1) by choosing $b_{i}$ and, if possible, $a_{i} \in\{0,1\}$. The first order condition for agent $i$ 's utility maximization problem is given by:

$$
\frac{\partial U_{i}}{\partial b_{i}}\left(b_{i}, a_{i}, g, \mu\right)=-1+h_{i}{ }^{\prime}(B)+f_{i}^{\prime}\left(b_{i}\right)+\frac{\partial r_{i}}{\partial b}\left(b_{i}, a_{i} \mu g\right) \leq 0
$$

\footnotetext{
${ }^{6}$ Note that this assumption is different from much of the literature on gift-exchange and may not hold for mail solicitations where donors would incur added costs to return the gift to the charity. We assume that if a donor rejects a gift, he receives the same utility as in a VCM setting. One could imagine that the act of offering a gift itself might lead to reciprocal behavior by a potential donor. Our predictions of the model therefore give a conservative estimate of the effect of gifts on donation decisions.
} 
and holds with equality if $b_{i}>0$. This leads to an optimal contribution level denoted by $b_{i}^{\text {opt }}(a, g, \mu)$. Importantly, condition (2) implicitly shows the extent to which the agent reciprocates gifts:

$$
\partial b_{i}^{\mathrm{opt}}(1, g, \mu) / \partial(\mu g)=-\mu \frac{\partial^{2} r_{i}}{\partial b \partial(\mu g)}\left(b_{i}, \mu g\right) / \frac{\partial^{2} r_{i}}{\partial b^{2}}\left(b_{i}, \mu g\right) \geq 0
$$

Intuitively, the effect of (accepted) gifts on contribution levels is increasing in the perceived generosity of the gift, $\mu$.

\section{Contribution Levels and Unconditional Gift Exchange}

We can now apply these preliminaries to examine how the way in which a charity elects to implement gift exchange influences donor behavior. From condition (3), we have that contributions are increasing in the size of an accepted gift for any agent with reciprocal preferences. Yet it need not be the case that all agents have reciprocal preferences and/or accept available gifts. However, in such instances, contribution decisions coincide with the voluntary contributions mechanism (VCM). We can summarize these results as follows:

Proposition 1. Provided at least some subset of agents has reciprocal preferences, the introduction of an unconditional gift unambiguously increases both the number of agents who contribute and average contribution levels.

Intuitively, provided agents can refuse an unconditional gift (UG), they cannot be made worse off than if the charity were to simply ask for a voluntary contribution. However, individuals with reciprocal preferences that accept an unconditional gift increase contributions relative to this baseline case. Thus, we would expect both higher participation rates and average contributions when a charity offers perspective donors an unconditional gift.

Before proceeding it is worth noting that Proposition 1 is at odds with the pure altruism model. Under this model, the sole impetus for donations is a concern for the well-being of others 
and aggregate public good provision. Hence, ulterior motives - i.e., reciprocity - should have no impact on donor behavior. As the receipt of unconditional gifts is delinked from contribution decisions, the pure altruism model would thus predict that unconditional gifts have no impact along either the intensive or extensive margins.

\section{Contribution Levels and Conditional Gift Exchange}

We distinguish between two different versions of conditional gifts (CG). In the first (or weak) version of conditionality, the gift is granted if the agent contributes any positive amount. The second version imposes a stronger constraint on the agent - the gift is only granted should they contribute more than a specified minimum amount, i.e. $b_{i} \geq b^{\min }>0$. In our model we assume that introducing stricter conditionality reduces the perceived generosity of the gift and thereby lowers $\mu$. That is we assume that $\mu^{\mathrm{CG}}<\mu^{\mathrm{UG}}$, where $\mu^{\mathrm{CG}}$ is decreasing in the required threshold $b^{\min }$. Hence, in the limit as $\mu \rightarrow 0$, both participation rates and average contribution levels will converge towards those observed in an equivalent $\mathrm{VCM}^{7}$

Unfortunately, the effect of changing the required minimum donation level is less clear. While an increase in $b^{\text {min }}$ serves to crowd reciprocity and therefore lowers the contributions of agents for whom $b_{i}^{\text {opt }}\left(1, g, \mu^{\mathrm{CG}}\right)>b^{\text {min }}$, it may also serve to crowd in contributions via a consumption effect. That is, agents who contribute exactly the minimum level $b^{\min }$ may increase their contributions so that they remain eligible to receive the gift. Importantly, however, all such agents will contribute $b^{\min }$ to "purchase" the conditional gift and we would thus expect to observe pooling at the required threshold.

\footnotetext{
${ }^{7}$ Of course, if one were to allow negative values for $\mu$ than it would be possible to observe lower participation rates and average contributions than in a VCM.
} 
Provided that demand for the gift is well-behaved, the number of agents that are willing to "purchase" the gift should be strictly decreasing in the threshold contribution level, $b^{\min }$. As such, we would expect participation rates to be strictly decreasing in this threshold level. Hence, as the required $b^{\min }$ grows sufficiently large, the relative importance of the consumption effect dwindles and donations will converge to those that would be elicited via a VCM. This suggests a second proposition:

Proposition 2. For agents with reciprocal preferences, imposing conditionality- i.e., requiring that $b>b^{\min }=0$ in order to receive a gift - leads to a decrease in average contributions. However, conditionality may "crowd-in" donors through a consumption effect and thus has an ambiguous effect on participation rates. Further increases in $b^{\text {min }}$ serve to crowd out donors but has an ambiguous effect on average contribution levels.

Proposition 2 highlights that the overall effect of changing $b^{\min }$ depends on the trade-off between two effects - the crowding of reciprocity and increased contributions by those who pool at $b^{\min }$ to "purchase" the gift. ${ }^{8}$

Net contributions to the charity

Since the provision of gifts is costly to the charity, the use of conditional gifts may prove a profit maximizing strategy for a charity in both the short- and long-runs. In the short-run, conditional gifts provide a way for the charity to screen donors and avoid entering into a giftrelationship with types for whom such a strategy is a net loser. In particular, the charity will want to avoid entering into a gift-exchange relationship with any agent for whom $\frac{\partial b_{i}^{o p t}}{\partial g}-1<0$ as such agents increase their contributions by less than the cost of the gift. Hence, providing

\footnotetext{
${ }^{8}$ Note that the latter effect is zero when moving from an unconditional gift to conditionality given by $b>b_{\min }=0$. The net effect on contributions of introducing conditionality without a positive minimum contribution is therefore predicted to be negative.
} 
such types an unconditional gift guarantees net losses for the charity that could be reduced by introducing conditionality to the gift-exchange relationship.

Further, by manipulating $b^{\min }$ the charity can increase contributions from any agent for whom the consumption effect applies - i.e., those who contribute exactly $b^{\min }$ in order to "purchase" the gift. However, there is a cost of conditionality - increasing $b^{\text {min }}$ crowds out participation and contributions from reciprocal types for whom $b_{i}^{\text {opt }}\left(1, g, \mu^{\mathrm{CG}}\right)>b^{\min }$. Which of these effects dominates in the short-run is ex ante unknown and will depend upon the realization of key model parameters.

In the long-run, the relative superiority of a particular form of gift exchange depends crucially on the persistence of reciprocity and the proportion of reciprocal types in the population. As noted above, unconditional gifts maximize the number of donors. As previous givers are more likely to contribute and provide larger average gifts than other donor types (Landry et al., 2010), it is thus plausible to intuit conditions under which unconditional gifts prove a superior fund-raising strategy in the long-run.

Yet, such conditions require that feelings of reciprocity, as triggered by the receipt of a gift in a prior fund-raising campaign, persist and influence behavior in subsequent fund-raising efforts. If not, our model predicts that those initially attracted via conditional gifts should be more likely to give and provide larger average donations. As conditionally serves to crowd reciprocity, reciprocal agents who contributed any given amount in a conditional gift treatment implicitly revealed a higher value for the public good than a counterpart contributing this same amount in an unconditional gift treatment. If feelings of reciprocity are fleeting, we would therefore expect donors initially attracted via conditional gifts to be weakly more loyal to the charity than counterparts who initially received the same gift unconditionally. 
That such possibility exists highlights a heretofore "hidden benefit" of control that arises as conditionality provides an effective technology for screening donors. Yet, such benefits are "hidden" in the sense that they would escape one's attention if reasoning were based upon the standard approach of using a static model and assuming that all donors are reciprocal. In such models, there is no benefit to screening donors and conditionality can only have negative impacts. However, as our model highlights, there are many reasons why a profit maximizing charity could benefit from screening donors.

\section{Experiment I - Design and Results}

To examine the main conjectures of our theory, we designed a door-to-door fund-raising natural field experiment. The experimental treatments are guided by our theory, and are meant to provide a test of its predictions. We make use of seven different treatments, composed of a VCM baseline and gift variants that include small and large gifts provided both conditionally and unconditionally.

\section{A. Experimental Treatments}

In each of the seven treatments, households in predetermined neighborhood blocks in Pitt County, North Carolina were approached by a paid solicitor and asked if they would like to make a contribution to support the Center for Natural Hazards Research at East Carolina University. ${ }^{9}$ Households that answered the door were provided an informational brochure detailing the activities of the Hazard Center since its inception in 2004 and read a fixed script that outlined the reason for the solicitors' visit. The script included a brief introduction that informed the resident

\footnotetext{
${ }^{9}$ The neighborhood blocks were selected to provide a representative sample of three distinct household types: (i) households that contributed to the Hazards Center in a previous fund-raising effort, (ii) households that were visited in previous fund-raising efforts but elected not to contribute, and (iii) households that did not speak to a solicitor in a previous fund-raising drive. A companion paper (Landry et al., 2010) explores these variations in more detail. For our purposes, we simply include controls for these different household types.
} 
of who the solicitors were, the purpose of their visit, a two-sentence summary of the non-profit organization, and when applicable a description of the gift (see the Appendix).

Our first two variations from the baseline VCM treatment are unconditional small and large gift treatments. For the small gift, we used an attractive bookmark with the Hazard Center or East Carolina University logo. For the large gift, we used a copy of the New York Times bestseller Freakonomics. In the small (large) unconditional gift treatment, we simply added the following to the baseline script:

As a token of our appreciation, we would like you to have this bookmark (copy of Freakonomics) as a gift to you. The bookmark (book) is yours to keep whether or not you make a donation.

These treatments permit a test of whether unconditional gifts enhance both the extensive and intensive margins, and whether the magnitude of such effects are related to gift size.

To operationalize exogenous changes in the perceived generosity of the gift we introduce a conditionality variant to these gift treatments by inserting the following passage in the baseline script:

As a token of our appreciation, we will give you this bookmark (copy of Freakonomics) as a gift should you make a donation today.

This treatment eliminates the agent's most opportune action—taking the gift and giving nothing. As such, this manipulation should change the perceived generosity of the gift compared to the unconditional case $\mu^{\mathrm{CG}}<\mu^{\mathrm{UG}}$.

Our final two treatments further restrict the action set by adding a price point to the unconditional gift:

As a token of our appreciation, we will give you this bookmark (copy of Freakonomics) as a gift should you make a donation of \$1 (\$25) today. 
Our price points were chosen to approximate the current retail price of the two goods. While these two treatments serve to follow our theory, the chosen price in the small gift treatment serves to present a particularly demanding test of theory. First, most donors likely will view any "restrictions" on actions as illusory since every contribution in our previous fund-raising drive for the Hazard Center (Landry et al., 2006) was $\$ 1$ or more. Second, the psychology literature teaches us that even solicitees who would like to contribute are largely unaware of the level of an acceptable donation, and therefore might refrain from giving merely because they want to avoid the social embarrassment of giving too little. ${ }^{10}$

An extension of this second line of reasoning provides an important reason why these treatments also present a particularly demanding test of our theory for the large gift treatment. Literature in psychology provides some empirical evidence that mention of a target donation amount serves to increase the response rate (see, e.g., Fraser et al., 1988; Briers et al., 2007). In this spirit, simply providing a goal of $\$ 25$ might serve to increase the number of donors. ${ }^{11}$

Table 1 summarizes the design of experiment I. The experimental treatments were conducted between April $21^{\text {st }}$ and June $24^{\text {th }}$, 2006 with six sessions conducted between 9am and $5 \mathrm{pm}$ on Saturday and another five sessions conducted on Wednesday and Thursday evenings between $5 \mathrm{pm}$ and $8 \mathrm{pm}$. Our design resulted in a sample size of 4283 total households approached -878 in the VCM, 768 in the unconditional small gift (USG), 610 in the unconditional large gift (ULG), 634 in the no price point conditional small gift (CSG-NPP), 380 in the price point conditional small gift (CSG-PP), 481 in the no price point conditional large gift

\footnotetext{
${ }^{10}$ While outside of our theory, this intuition has some empirical support. For instance, Cialdini and Schroeder (1976) found that in a door-to-door charity drive including the quip "even a penny will help" considerably increased the number of donations without adversely affecting the average contribution.

${ }^{11}$ For further information about the actual exchange of information, we direct the reader to the Appendix, which contains a copy of the informational brochure and script.
} 
(CLG-NPP), and 532 in the price point conditional large gift (CLG-PP) treatment. Of the households approached, 1381 answered the door and spoke to a solicitor.

\section{B. Recruiting and Training of Solicitors}

As Table 1 reveals, we employed a within-solicitor design using a total of thirty-six unique solicitors. Of the thirty-six total solicitors, nineteen participated in the VCM treatment, nineteen participated in the unconditional small gift treatment, twenty-two participated in the conditional small gift treatment, thirteen participated in the unconditional large gift treatment, and seventeen participated in conditional large gift treatment. ${ }^{12}$ To control for possible order effects, solicitors were randomly assigned to treatments, and we were careful to run multiple treatments on every day of the experiment.

Each solicitor's experience typically followed four steps: (1) consideration of an invitation to work as a paid employee of the Center, (2) an in-person interview, (3) a training session, and (4) participation as a solicitor in the campaign. ${ }^{13}$ Undergraduate solicitors were recruited from the student body at ECU via flyers posted around campus, announcements on a university electronic bulletin board, advertisements in the local campus newspaper, and direct appeal to students during undergraduate economics courses. All potential solicitors were told that they would be paid $\$ 10$ per hour during training and employment and would be expected to work multiple days. Interested solicitors were instructed to contact the Economics Department to schedule an interview.

Before proceeding to the results section, we should highlight a few important design issues. First, every applicant was offered employment as a solicitor after completing an in-

\footnotetext{
${ }^{12} \mathrm{Six}$ of the solicitors only participated in a single treatment. Of the remaining thirty solicitors, sixteen participated in two different treatments and fourteen participated in three or more different treatments. No single solicitor participated in all seven treatments.

${ }^{13}$ See Landry et al. (2006) for further details on recruitment; we followed their study in this regard.
} 
person interview. Second, the training sessions were conducted by the same researcher and provided the solicitor with background information on the Hazard Center and a review of the solicitation script and data collection procedures. Third, each solicitor wore an identification badge that included his or her picture, name, and city solicitation permit number. Fourth, we randomly allocated solicitors across neighborhoods and treatment type, and solicitors remained in the same treatment throughout each given day. Finally, after every interaction with a household, each solicitor filled out data collection forms that included the amount donated along with demographic data such as the estimated age, gender, and race of the potential contributor.

\section{Experimental Findings}

Table 2 summarizes donor behavior, as well as solicitor and household characteristics across treatment. For example, our solicitors approached 878 households in the VCM treatment and elicited contributions from 21.3 percent (61 out of 286) of those who answered the door. The average donation amount was $\$ 1.90$ per solicitation; therefore, we raised $\$ 541.35$ in the VCM treatment. In total we raised approximately $\$ 3333(\sim \$ 2.40$ per solicitation) for the Hazard Center. Further scrutiny of the data leads to our first set of results on unconditional gifts:

Result 1a: Unconditional large gifts enhance both the extensive and intensive margins.

Result 1b: The size of the unconditional gift importantly influences donor behavior.

These first two results are consonant with our theoretical model and share similarity with the findings reported in Falk (2007), who explored the importance of gift exchange in a mail solicitation fund-raiser. Moreover, these results call into question "pure" altruism as a driver of donor behavior. Under the "pure altruism" model, ulterior motives - i.e., reciprocity - should have no impact on donor behavior as the receipt of unconditional gifts is delinked from the contribution decision. 
Casual evidence for these two results is contained in Table 2. First, we find that in the raw data, neither the propensity to contribute (22\% vs. $21.3 \%)$ nor the average contributions (\$1.73 vs. \$1.90) are significantly different across the unconditional small gift treatment and the baseline VCM treatment. Yet, we find that both figures are considerably larger in the unconditional large gift treatment: nearly twice as many solicitees contribute (36.8\% vs. $21.3 \%)$, and give more than twice as much on average (\$4.48 vs. \$1.90). Both of these results are statistically significant at conventional levels $(\mathrm{p}<.05)$ using both a parametric matched pairs ttest and a non-parametric Wilcoxon signed-rank test. ${ }^{14}$

To complement these unconditional insights, we estimate a series of linear regression models that explicitly control for observable and unobservable differences across solicitors. This analysis is important because such factors might systematically differ across treatment, leading to erroneous inference from a simple analysis of the raw data. Specifically, we estimate a linear regression model of the amount contributed for each household that answered the door (including zero contributions) on dummy variables for our experimental treatments and other covariates:

$$
L_{i j}=Z_{i j} \delta+X_{i j} \beta+\varepsilon_{i j}
$$

where $L_{i j}$ is the contribution level of the $j^{\text {th }}$ household to the $i^{\text {th }}$ solicitor, $\mathbf{Z}$ is a vector of treatment group status indicators, and $\mathbf{X}$ is a vector of other covariates - including observable characteristics of potential donors. To account for unobservable heterogeneities at the solicitor level, we include solicitor fixed effects. ${ }^{15}$

\footnotetext{
${ }^{14}$ The unit of observation in each of these tests is solicitor specific averages for a particular treatment. The test statistic is thus based on the distribution of the difference in these solicitor specific averages between the unconditional large (small) gift treatment and the baseline VCM. Using such matched pairs tests controls for potential solicitor specific dependencies across treatments.

${ }^{15}$ Qualitative insights are similar if we use a Tobit specification or if we estimate equations (4) and (5) with a standard two-stage selection equation with the yes-no contribution decision modeled in the first stage and the dollars
} 
Empirical estimates presented in Model A of Table 3 provide insights consistent with the unconditional results: households contributed approximately \$2.66 more in the unconditional large gift treatment than in the baseline VCM treatment, with this difference statistically significant at the $\mathrm{p}<0.05$ level. Further insights garnered from Table 3 suggest that donors respond to the perceived value of a gift as predicted by our theoretical model. On average, households contributed approximately $\$ 2.60$ more when receiving a copy of Freakonomics rather than a bookmark, with this difference significant at the $\mathrm{p}<0.05$ level. Empirical results are qualitatively consistent across richer models that account for more of the variation in the data (see Models B and C in Table 3).

To gain insights into the factors that influence the decision of households to contribute to the Hazard Center, we estimate a linear probability model of the contribution decision of households that answered the door:

$$
C_{i j}=Z_{i j} \delta+X_{i j} \beta+e_{i j}
$$

where $C_{i j}$ equals unity if solicitor $i$ received a contribution for household $j$, and equals zero otherwise. We again include solicitor fixed effects and three model types, which all paint a similar picture.

Empirical estimates are presented in Model A of Table 4, and again indicate that gifts, as well as their size, matters. For example, we find that households were more likely to contribute when approached by a solicitor in one of our gift treatments: households are approximately 23 percent (10 percent) more likely to contribute in the unconditional large (small) gift treatment. Interestingly, both of these estimates are significantly different from zero, suggesting that the small gift has some import on the extensive margin. Yet, the approximate 13 percent difference

contributed in the second. Also, all reported empirical results are robust to models that augment $X$ to include additional household controls such as donor age and previous contributions to the Hazards Center. 
in contribution rates across the unconditional large and small gift treatments is significant at the $\mathrm{p}<0.05$ level.

Turning to the effects of our conditional gift treatments, we report a second set of results:

Result 2a: Providing donors with a conditional, rather than an unconditional, gift decreases participation rates and average donations per contact.

Result 2b: Both rates of giving and average donations per contact are lower when we increase control and require a $\$ 25$ donation to obtain the large gift.

Result 2c: Conditionality induces an increased propensity for donors to pool at the minimum donation level required to receive the gift.

Evidence for Results $2 a$ and $2 b$ can be found in Tables 2-4. For example, summary results in Table 2 show that both average contributions per contact and participation rates are reduced when we move from the unconditional large gift treatment to a conditional large gift treatment. Participation rates (average contributions) in our no price point treatment are approximately 4.6 percent $(\$ 2.20)$ lower than those observed when donors are provided the large gift unconditionally. Interestingly, we observe no such crowding out in our small gift treatments, perhaps suggesting that the bookmark is unable to generate feelings of reciprocity.

To complement these insights, we return to the empirical estimates in Tables 3 and 4 which control for unobserved heterogeneity across solicitors in a fixed effects regression model. Model A of Table 3 shows that average donations per contact are approximately $\$ 1.64(\$ 2.06)$ lower in the conditional no price point (conditional price point) large gift treatment than in the analogous unconditional large gift treatment, with both of these differences significant at the $p<$ 0.05 level. This former difference is consonant with Proposition 2 which predicts a net reduction in average contributions when moving from an unconditional gift treatment to a conditional gift treatment requiring a minimum donation of $b>b^{\min }=0$ to receive the gift. Further, that we find 
an inverse relationship between $b^{\min }$ and average donations suggests that crowding dominates consumption effects in our setting.

Considering average participation rates, we observe that households are less likely to contribute to the Hazard Center when offered a large gift conditionally. As noted in Model A of Table 4, a household is approximately 2 percent (18 percent) less likely to contribute when receiving the large gift, conditioned upon making a donation of any amount $(\$ 25)$ to the Hazard Center. While this former difference is not significant at any meaningful level, the difference in participation rates between the CLG price point treatment and both the ULG and CLG no price point treatments is statistically significant at the $\mathrm{p}<0.05$ level. Empirical results for the small gift treatment highlight that the extensive margin is considerably enhanced by providing social cover for low donations. This result accords with Cialdini and Schroeder (1976) and the broad literature, mostly in psychology and marketing, that has followed (for a review see, e.g., Brockner et. al., 1984; Fraser et al., 1998).

Evidence for Result 2c can be found in Figures 1 and 2, which show histograms of donations in our VCM and three small (large) gift treatments. As illustrated in Figure 1, there is an increased propensity for agents to pool at the $\$ 1.00$ contribution level in our price point treatment. While approximately 2.04 percent of all households approached contribute $\$ 1.00$ in our unconditional small gift treatment, the percentage of households approached that contribute this amount in the corresponding price point treatment increases to approximately 13 percent. Using a two-sample test of proportions, the more than six-fold increase is statistically significant at the $\mathrm{p}<0.01$ level.

We observe similar data patterns in our large gift treatments. As illustrated in Figure 2, the percentage of households approached that contribute $\$ 1.00(\$ 25.00)$ in our no price point 
(price point) treatments is greater than the corresponding percentage of households contributing these amounts in the analogous unconditional gift treatment. While approximately 1.9 percent (2.4 percent) of all households contribute $\$ 1.00(\$ 25.00)$ in our unconditional large gift treatment, the respective percentage in the equivalent no price point (price point) treatment is 4.9 percent (6.8 percent). Using a two-sample test of proportions, we find that the former 3 percentage point difference is statistically significant at the $p<0.10$ and that the latter 4.4 percentage point difference is significant at the $\mathrm{p}<0.05$ level.

Our analysis has thus far concentrated on gross proceeds. From the perspective of a charitable organization, it is clearly of interest to further examine net public good provisionaverage contributions less the costs of purchasing the gifts. In this regard, we present a final result:

Result 3: In the short-run, the VCM and the gift treatments that eliminate the agent's most opportunistic actions maximize public good provision.

Evidence for Result 3 is provided in the final panel of Table 2 - net public good provision per household in our large gift treatments is monotonically increasing in the level of conditionality. As noted in the table, gross proceeds in both our unconditional and no price point large gift treatments were insufficient to cover the costs of purchasing the copies of Freakonomics. As such, net revenues per contact in these treatments are significantly lower than the $\$ 1.90(\$ 1.75)$ figure observed in our baseline VCM (price point large gift) treatment at the $\mathrm{p}<0.05$ level. Furthermore, the approximate $\$ 1.41$ difference in net revenues per contact across our ULG and no price point treatments is statistically significant at the $\mathrm{p}<0.10$ level. Interestingly, we observe no discernable difference in net revenues across our small gift treatments and the VCM, again highlighting that the bookmark may not induce feelings of reciprocity. 
Exploring this result a level deeper, approximately 37.2 percent of all non-donors in our unconditional large gift treatment keep the copy of Freakonomics - generating losses in the range of $\$ 1.13$ per household contacted. Amongst the set of donors, approximately 69.2 percent (45 out of 65) of those who kept the copy of Freakonomics provided gifts less than the $\$ 12.98$ cost of obtaining the book. For no price point large gift treatment, approximately 81.1 percent (30 out of 37) of all donors kept the book but provided donations less than this amount. Taken jointly, these data suggest that there are a non-trivial number of types in the population for whom entering into a gift-exchange relationship is a losing proposition. Hence, altering $b^{\text {min }}$ to "screen" such types proves a profit enhancing strategy for the Hazard Center.

\section{Experiment II - Design and Results}

Results from experiment I highlight that in the short-run, the charity is better off providing gifts conditionally in order to screen insufficiently-reciprocal types for whom gift exchange is a net loser. However, as conditional gifts serve to crowd out donors, it is not clear whether conditionality is an optimal strategy in the long-run. As noted in Landry et al. (2010), previous givers to the Hazard Center are approximately 19 percent more likely to contribute in future campaigns and provide average gifts that are roughly twice as large as counterparts who have never given. Given that households in our unconditional large gift treatment were approximately 74.4 percent more likely to give than counterparts approached in the corresponding price point treatment, it is thus plausible to intuit conditions under which unconditional gifts prove a superior fund-raising mechanism in the long-run.

However, fundamental to any such story is the assumption that, once triggered, feelings of reciprocity influence behavior in subsequent fund-raising efforts. Yet, whether and the extent to which feelings of reciprocity are sustained across campaigns is ex ante unknown. As such, 
data from experiment I provides little insight regarding long-run dynamics and the relative superiority of conditional versus unconditional gifts. To better ascertain long-run impacts, we return to the field and implement a second door-to-door fund-raising experiment during.

\section{A. Experimental Design}

In designing the second field experiment, we made use of detailed information on whether and how households were previously approached. Households in predetermined neighborhood blocks in Pitt County, North Carolina were approached by a paid solicitor and asked if they would like to make a contribution to support the Hazard Center using a simple ask strategy (or voluntary contribution mechanism). The neighborhood blocks were selected to provide a representative sample of two distinct household types: (i) households that have never contributed to the Hazard Center (cold-list households), and (ii) households that were approached and contributed to the Hazard Center (warm-list households) in experiment I. As small gifts (the bookmarks) had no discernable impact on outcomes in experiment I, we restrict the sample of warm-list households to those who were previous approached in either the VCM or one of the three large-gift treatments.

As in experiment I, households that answered the door were provided an informational brochure detailing the activities of the Hazard Center and read a fixed script that outlined the reason for the solicitor's visit. The script included a brief introduction that informed the resident of the purpose of their visit and noted that all proceeds raised in the fundraising campaign would be used to fund research that benefits Pitt County and the surrounding area.

Table 5 summarizes the design for experiment II. Fund-raising efforts were initiated on September $12^{\text {th }}, 2009$ and continued through the $16^{\text {th }}$ of that month. We employed a total of fifty-five solicitors who worked three hour shifts starting between 9 to 10am on Saturday 
morning, 1 to $2 \mathrm{pm}$ on both Saturday and Sunday afternoon, and at $5 \mathrm{pm}$ on both Tuesday and Wednesday evenings. ${ }^{16}$ Our design resulted in a sample size of 2772 total households approached. Of the households approached, 1074 answered the door and spoke with a solicitor 833 who did not speak to a solicitor in experiment I, 62 drawn from the VCM treatment in experiment I, 65 drawn from the Unconditional Large Gift treatment in experiment I, and 114 drawn from a Conditional Large Gift treatment in experiment I. ${ }^{17}$ The solicitation approach mirrors the design of experiment I.

\section{B. Experimental Findings}

Table 6 presents summary statistics including information on the success of solicitors across different household types. For example, as noted in the table, solicitors spoke with 62 households who were approached in the VCM treatment in experiment I. Of these, approximately 22.6 percent (or 14 of 62 ) contributed to the Hazard Center. In total, our solicitors raised $\$ 1914.72$ (or approximately $\$ 1.78$ per solicitation) for the Hazard Center: $\$ 1532.72$ (or $\$ 1.84$ per solicitation) from households not solicited in experiment I, \$103 (or \$1.66 per solicitation) from households previously solicited using a VCM, \$69 (or \$1.06 per solicitation) from households previously solicited in the unconditional large gift treatments, and $\$ 210$ (or $\$ 1.84$ per solicitation) from households previously solicited in a conditional large gift treatment. $^{18}$

The Dynamics of Unconditional Gifts

\footnotetext{
${ }^{16}$ The recruiting and training of solicitors followed the same procedures as those used in experiment I.

${ }^{17}$ In analyzing the data from experiment II, we pool HH's initially approached in the no price point and price point large gift treatments as participation rates and average contribution levels are indistinguishable across these two groups.

${ }_{18}$ The set of previously approached households includes both prior contributors to the Hazard Center and those who elected not to give in the prior fund-raising effort.
} 
Table 6 summarizes donor behavior, as well as household characteristics across different household types. As noted in the table, our solicitors elicited contributions from 14.3 percent (4 of 28) of warm-list households initially attracted via an unconditional large gift. In contrast, solicitors approaching a warm-list household initially attracted via a conditional large gift were approximately 151 percent more likely to elicit a contribution. Importantly, this difference is significant at the $\mathrm{p}<0.05$ level using a two sample test of proportions. We observe similar, albeit less pronounced, differences when comparing participation rates against those initially attracted via a simply ask for money (VCM).

Exploring average contributions, we observe similar differences across the same household types. The $\$ 1.29$ average contribution from households initially attracted via an unconditional gift is approximately 63 percent (29.5 percent) lower than that elicited from counterparts initially attracted by a conditional large gift (VCM). While the latter difference is not significant at meaningful levels, the former is significant at the $\mathrm{p}<0.05$ level using either a parametric t-test or non-parametric Wilcoxon rank-sum test. Taken jointly, these data suggest a fourth result:

Result 4: Donors initially attracted via unconditional gifts are less loyal to the cause than counterparts attracted by conditional gifts or a VCM.

Importantly, Result 4 suggests that feelings of reciprocity - triggered by the receipt of an unconditional gift - are short-lived and have little impact on subsequent behavior. Hence, while data from experiment I suggest the importance of gift exchange, results from experiment II highlight that the effects of gift exchange are contemporaneous and reciprocity is limited to the immediate source of kindness. 
To complement these unconditional insights, we estimate a series of linear regression models that explicitly control for observable differences across households and unobservable differences across solicitors. In this spirit, we estimate linear regression models of the amount contributed for each household that answered the door (including zero contributions) on dummy variables for our experimental treatments and other covariates:

$$
L_{i j}=Z_{i j} \delta+X_{i j} \beta+\varepsilon_{i j}
$$

where $L_{i j}$ is the contribution level of the $j^{\text {th }}$ household to the $i^{\text {th }}$ solicitor, $\mathbf{Z}$ is a vector of treatment group status indicators, and $\mathbf{X}$ is a vector of other covariates - including observable characteristics of potential donors. To account for unobservable heterogeneities at the solicitor level, we include solicitor fixed effects.

Empirical estimates presented in Model A of Table 7 provide insights consistent with the raw data summary: donors initially attracted by an unconditional gift contribute approximately $\$ 2.28$ less than counterparts initially attracted by a conditional gift - a difference that is statistically significant at the $\mathrm{p}<0.05$ level. Further insights garnered from Table 7 highlight that there is no discernable difference in the contributions of households initially attracted via an unconditional gift and those who originally gave in a VCM. ${ }^{19}$ Empirical results are qualitatively consistent models B and C which include additional household level controls.

To gain insights into the factors that influence the decision of households to contribute to the Hazard Center, we estimate a linear probability model of the contribution decision of households that answered the door:

$$
C_{i j}=Z_{i j} \delta+X_{i j} \beta+e_{i j}
$$

\footnotetext{
${ }^{19}$ Interestingly, our data suggest that the manner in which cold-list households - i.e., those who were approached but did not give in experiment I - were initially approached has no impact on future contribution levels.
} 
where $C_{i j}$ equals unity if solicitor $i$ received a contribution for household $j$, and equals zero otherwise. We again include solicitor fixed effects and three model types, which all paint a similar picture.

For example, empirical estimates in Model A of Table 8 suggest that households initially attracted via an unconditional gift are approximately 79.5 percent less likely to contribute than counterparts initially attracted via a conditional large gift - a difference that is significant at the $p$ $<0.05$ level. Similarly, such households are approximately 55.5 percent less likely to contribute than counterparts initially attracted via a VCM - a difference that is significant at the $p<0.10$ level. Estimates for Models B and C provide similar insights and highlight that observable characteristics such as the race, gender and the age of potential donors influence participation rates.

Viewed in conjunction with results from experiment I, our data therefore suggest that unconditional gifts are a bad investment for the Hazard Center. In the short-run, the use of such gifts enhances participation rates and gross proceeds per contact. However, the increased participation rates and average gifts come at a cost - approximately 23.4 percent of all households approached keep the gift but do not contribute to the Hazard Center. In the long-run, donors attracted to the Hazard Center using unconditional gifts are less likely to contribute and provide lower average donations than counterparts attracted by other means. Hence, the Hazard Center is unable to recover the short-run losses associated with the use of unconditional gifts and would have been better off relying upon other fund-raising strategies - i.e., simple asks for money or the provision of conditional gifts.

The Dynamics of Conditional Gifts and Net Charitable Revenue 
Having explored the dynamics of unconditional gifts, we now examine the relative longrun impact of conditional gifts vis-à-vis a simple ask strategy. Results from experiment I highlight that in the short-run, there is no discernable difference across these treatments. Hence, the charity is indifferent between the use of simple asks for money and providing donors a conditional gift. Yet, as donors in the conditional gift treatment provide average contributions that are approximately 30 percent greater than counterparts initially approached in a VCM, it would be intuitive to posit that conditional gifts will have a greater impact on subsequent fundraising efforts.

Data from experiment II allow us to explore this conjecture and suggest a fifth result:

Result 5: Donors initially attracted via a conditional gift are more loyal to the cause than counterparts attracted via a VCM.

To provide evidence for this result, consider the raw data summary in Table 6. Warm-list households attracted through a conditional gift treatment are approximately 25.5 percent more likely to give (35.9 versus 28.6 percent) than counterparts initially approached in a VCM and provide average gifts that are approximately 90.7 percent greater $(\$ 3.49$ versus $\$ 1.83)$ than such types - differences that are significant at the $\mathrm{p}<0.10$ and $\mathrm{p}<0.05$ levels respectively.

Additional support for Result 5 is contained in Tables 7 and 8 which condition participation rates and contribution levels on observable household characteristics and unobservable solicitor specific effects. For example, as noted in Model A of Table 7, households initially attracted via a conditional gift provide average gifts that are approximately $\$ 2.28$ (or 186.9 percent) greater than counterparts initially attracted via a $\mathrm{VCM}$ - a difference that is significant at the $\mathrm{p}<0.05$ level. Model A in Table 8 , highlights similar differences in regards to participation rates: donors initially attracted via a conditional gift are approximately 116.7 
percent more likely to contribute than a counterpart who originally gave in a VCM. Estimates from Models $\mathrm{B}$ and $\mathrm{C}$ of these tables provide qualitatively similar insights and highlight the robustness of this result to the inclusion of additional household level controls.

Combined with results from experiment I, our data therefore suggest that conditional gift exchange provides a superior fund-raising mechanism. For academics, this result calls into question results from the laboratory suggesting that the use of explicit incentives - such as

conditional rewards and punishment - entail considerable "hidden" costs (see, e.g., Fehr and Rockenbach, 2003; Fehr and List, 2004; Falk and Kosfeld, 2006). Although we cannot rule out that some individuals respond adversely to conditional gifts, 'control' as defined in the literature provides a means for the Hazard Center to enhance the profitability of its fund-raising efforts. In this regard, our data highlight a "hidden benefit" of control in that such mechanisms provide a way to screen donors - an effect that would escape our attention if reasoning had we followed the standard approach in the literature of using a static model and experimental design that measures short-run substitution effects. For practitioners, this result highlights the benefits of using mechanisms such as conditional gifts that serve to screen insufficiently-reciprocal types and those with "low" intrinsic value for the charity.

\section{Conclusions}

A cornerstone of the recent ascension of behavioral economics is the study of the interaction of psychological and economic incentives. This study takes this line of work to the field by making use of a series of field treatments that parallel some of the important economic features of the environments explored in the literature. Our approach uses an actual capital campaign that raised thousands of dollars for the Center for Natural Hazards Research at East 
Carolina University. Importantly, we use natural incentives to change exogenously the solicitees' action space to test for hidden benefits or costs of control.

Our results can be broken down into three main categories. First, we report results that highlight why people give to charity and why they remain committed the cause. In this manner, we find that the pure altruism model can be rejected, and that fundraising practitioners can effectively use gifts to enhance fundraising success. Second, there are hidden benefits of control: fundraising success is enhanced when the most opportunistic donor choices are restricted. This occurs not only because of short run benefits, but also because conditionality can be used as a screen of donor type. Finally, we find considerable evidence of the efficacy of gift exchange in the field but note that the effects of gift exchange are purely contemporaneous. This suggests that the static experimental designs that are meant to measure the effects of gift exchange provide a good approximation to the total effects. 


\section{References}

Alpizar, Francisco, Frederik Carlsson, and Olof Johansson-Stenman, “Anonymity, Reciprocity, and Conformity: Evidence from Voluntary Contributions to a National Park in Costa Rica," Journal of Public Economics, 92 (2008), pp. 1047 - 1060.

Andreoni, James, "Giving with Impure Altruism: Applications to Charity and Ricardian Equivalence," Journal of Political Economy, 97 (1989): 1147-1458.

—, "Impure Altruism, and Donations to Public Goods: A Theory of Warm-Glow Giving," The Economic Journal, 100 (1990): 464-477.

—, "Leadership Giving in Charitable Fund-Raising," Journal of Public Economic Theory, 8 (2006): 1-22.

Briers, Barbara, Mario Pandelaere, and Luk Warlop. "Adding Exchange to Charity: A Reference Price Explanation,” Journal of Economic Psychology, 28 (2007): 15-30.

Brockner, J, B. Guzzi, J. Kane, E. Levine, and K. Shaplen, “Organizational Fundraising: Further Evidence on the Effect of Legitimizing Small Donations," Journal of Consumer Research, 11 (1984): 611-614.

Cialdini, Robert B. and David A. Schroeder. "Increasing Compliance by Legitimizing Paltry Contributions: When Even a Penny Helps," Journal of Personality and Social Psychology, 34 (1976): 599-604.

Edlund, J., B. Sagarin, and B. Johnson. "Reciprocity and the Belief in a Just World," Personality and Individual Differences, 43 (2007): 589-596.

Falk, Armin, "Gift Exchange in the Field," Econometrica, 75 (2007): 1501-1512.

Falk, Armin and Michael Kosfeld. "The Hidden Costs of Control," American Economic Review, 96 (2006): 1611-1630. 
Fehr, Ernst and John A. List. "The Hidden Costs and Returns of Incentives - Trust and Trustworthiness among CEOs," Journal of the European Economic Association, 2 (2004): 743-771.

Fehr, Ernst and Bettina Rockenbach, "Detrimental Effects of Sanctions on Human Altruism," Nature, 422 (2003): 137-140.

Fraser, Cynthia, Robert E. Hite, and Paul L. Sauer, "Increasing Contributions in Solicitation Campaigns: The Use of Large and Small Anchorpoints," Journal of Consumer Research, 15 (1988): 284-287.

Landry, Craig, Andreas Lange, John A. List, Michael K. Price, and Nicholas G. Rupp. "Toward and Understanding of the Economics of Charity: Evidence from a Field Experiment," Quarterly Journal of Economics, 121 (2006): 747-782.

Landry, Craig E., Andreas Lange, John A. List, Michael K. Price, and Nicholas G. Rupp, "Is a Donor in Hand Better than Two in the Bush? Evidence from a Natural Field Experiment," American Economic Review, 100 (2010): pp. 958-983.

Landry, Craig E., Andreas Lange, John A. List, Michael K. Price, and Nicholas G. Rupp, "Is There a 'Hidden Cost of Control' in Naturally-Occurring Markets? Evidence from a Natural Field Experiment,” Working Paper, University of Tennessee, Knoxville (2011).

List, John A. and David Lucking-Reiley. "Effects of Seed Money and Refunds on Charitable Giving: Experimental Evidence from a University Capital Campaign,” Journal of Political Economy, 110 (2002): 215-233.

Regan, Dennis T. "Effects of Favor and Liking on Compliance," Journal of Experimental Social Psychology, 7 (1971): 627-639. 
Sliwka, Dirk. "Trust as a Signal of a Social Norm and the Hidden Costs of Incentive Schemes," American Economic Review, 97 (2007): 999-1012.

Vesterlund, Lise, "The Informational Value of Sequential Fundraising," Journal of Public Economics, 87 (2003): 627-657.

Whatley, M.A., J.M. Webster, R.H. Smith, and A. Rhodes, "The Effect of a Favor on Public and Private Compliance: How Internalized is the Norm of Reciprocity," Basic and Applied Social Psychology, 21 (1999): 251-259. 
Table 1: Design - Experiment I

\begin{tabular}{|c|c|c|c|c|c|c|c|}
\hline & $\begin{array}{c}\text { Voluntary } \\
\text { Contribution } \\
\text { Mechanism } \\
\end{array}$ & $\begin{array}{l}\text { Unconditional } \\
\text { Small Gift }\end{array}$ & $\begin{array}{c}\text { No Price Point } \\
\text { Conditional } \\
\text { Small Gift }\end{array}$ & $\begin{array}{c}\text { Price Point } \\
\text { Conditional } \\
\text { Small Gift } \\
\end{array}$ & $\begin{array}{l}\text { Unconditional } \\
\text { Large Gift }\end{array}$ & $\begin{array}{c}\text { No Price Point } \\
\text { Conditional } \\
\text { Large Gift }\end{array}$ & $\begin{array}{c}\text { Price Point } \\
\text { Conditional } \\
\text { Large Gift }\end{array}$ \\
\hline $\begin{array}{l}\text { Session 1 } \\
\text { April 22 }{ }^{\text {nd }}\end{array}$ & $\begin{array}{l}6 \text { Solicitors } \\
168 \text { Visit } \\
69 \text { Home }\end{array}$ & $\begin{array}{l}7 \text { Solicitors } \\
201 \text { Visit } \\
90 \text { Home }\end{array}$ & $\begin{array}{l}\text { 7 Solicitors } \\
339 \text { Visit } \\
102 \text { Home }\end{array}$ & & & & \\
\hline $\begin{array}{l}\text { Session } 2 \\
\text { April } 29^{\text {th }}\end{array}$ & $\begin{array}{l}\text { 3 Solicitors } \\
162 \text { Visit } \\
55 \text { Home }\end{array}$ & $\begin{array}{l}5 \text { Solicitors } \\
239 \text { Visit } \\
78 \text { Home }\end{array}$ & $\begin{array}{l}\text { 6 Solicitors } \\
295 \text { Visit } \\
97 \text { Home }\end{array}$ & & $\begin{array}{l}\text { 4 Solicitors } \\
190 \text { Visit } \\
77 \text { Home }\end{array}$ & $\begin{array}{l}3 \text { Solicitors } \\
223 \text { Visit } \\
73 \text { Home }\end{array}$ & \\
\hline $\begin{array}{l}\text { Session } 3 \\
\text { May } 3^{\text {rd }}-4^{\text {th }}\end{array}$ & $\begin{array}{l}\text { 4 Solicitors } \\
181 \text { Visit } \\
71 \text { Home }\end{array}$ & & & & & $\begin{array}{l}\text { 4 Solicitors } \\
258 \text { Visit } \\
70 \text { Home }\end{array}$ & \\
\hline $\begin{array}{l}\text { Session } 4 \\
\text { May } 6^{\text {th }}\end{array}$ & & $\begin{array}{l}3 \text { Solicitors } \\
198 \text { Visit } \\
62 \text { Home }\end{array}$ & & & $\begin{array}{l}3 \text { Solicitors } \\
171 \text { Visit } \\
49 \text { Home }\end{array}$ & & \\
\hline $\begin{array}{l}\text { Session } 5 \\
\text { June } 7^{\text {th }}\end{array}$ & $\begin{array}{l}3 \text { Solicitors } \\
66 \text { Visit } \\
24 \text { Home }\end{array}$ & & $\begin{array}{l}3 \text { Solicitors } \\
92 \text { Visit } \\
28 \text { Home }\end{array}$ & & & $\begin{array}{l}3 \text { Solicitors } \\
74 \text { Visits } \\
40 \text { Home }\end{array}$ & \\
\hline $\begin{array}{l}\text { Session } 6 \\
\text { June } 10^{\text {th }}\end{array}$ & $\begin{array}{l}\text { 3 Solicitors } \\
244 \text { Visit } \\
52 \text { Home }\end{array}$ & & & $\begin{array}{l}2 \text { Solicitors* } \\
25 \text { Visit } \\
8 \text { Home }\end{array}$ & $\begin{array}{l}\text { 4 Solicitors } \\
177 \text { Visit } \\
58 \text { Home }\end{array}$ & & $\begin{array}{c}\text { 4 Solicitors } \\
269 \text { Visit } \\
70 \text { Home }\end{array}$ \\
\hline $\begin{array}{l}\text { Session } 7 \\
\text { June } 15^{\text {th }}\end{array}$ & $\begin{array}{l}2 \text { Solicitors } \\
57 \text { Visit } \\
15 \text { Home }\end{array}$ & & & $\begin{array}{l}5 \text { Solicitors } \\
147 \text { Visit } \\
43 \text { Home }\end{array}$ & & & $\begin{array}{l}2 \text { Solicitors } \\
45 \text { Visit } \\
18 \text { Home }\end{array}$ \\
\hline $\begin{array}{l}\text { Session } 8 \\
\text { June } 17^{\text {th }}\end{array}$ & & $\begin{array}{l}2 \text { Solicitors } \\
51 \text { Visit } \\
15 \text { Home }\end{array}$ & & $\begin{array}{l}2 \text { Solicitors } \\
92 \text { Visit } \\
20 \text { Home }\end{array}$ & $\begin{array}{l}1 \text { Solicitor } \\
29 \text { Visit } \\
7 \text { Home }\end{array}$ & & $\begin{array}{c}2 \text { Solicitors } \\
57 \text { Visit } \\
15 \text { Home }\end{array}$ \\
\hline $\begin{array}{l}\text { Session } 9 \\
\text { June } 22^{\text {nd }}\end{array}$ & & & & $\begin{array}{l}1 \text { Solicitor } \\
18 \text { Visit } \\
8 \text { Home }\end{array}$ & $\begin{array}{c}2 \text { Solicitors } \\
43 \text { Visit } \\
18 \text { Home }\end{array}$ & & \\
\hline $\begin{array}{l}\text { Session } 10 \\
\text { June } 24^{\text {th }}\end{array}$ & & & & $\begin{array}{l}2 \text { Solicitors } \\
85 \text { Visit } \\
31 \text { Home }\end{array}$ & & & $\begin{array}{l}2 \text { Solicitors } \\
87 \text { Visit } \\
18 \text { Home }\end{array}$ \\
\hline
\end{tabular}

Note: Each cell represents one unique session in which we gathered data using one of the five treatments. For example, row 1, column 1, denotes that session one of the VCM treatment employed six solicitors that approached a total of 168 houses, of which 69 answered the door. All conditional gift treatments run during the month of June required a minimum donation of \$1 (\$25) to obtain a bookmark (copy of Freakonomics).

* In this treatment the solicitors only worked 2 hours before quitting due to illness. 
Table 2: Summary Statistics - Experiment I

\begin{tabular}{|c|c|c|c|c|c|}
\hline & $\begin{array}{c}\text { VCM } \\
\text { Treatment }\end{array}$ & $\begin{array}{c}\text { USG } \\
\text { Treatment }^{a}\end{array}$ & $\begin{array}{c}\text { CSG } \\
\text { Treatment }\end{array}$ & $\begin{array}{c}\text { ULG } \\
\text { Treatment }\end{array}$ & $\begin{array}{c}\text { CLG } \\
\text { Treatment }\end{array}$ \\
\hline \multicolumn{6}{|l|}{ Contribution Decisions } \\
\hline \multicolumn{6}{|l|}{ All Data Pooled } \\
\hline HH's Approached & 878 & 768 & 1014 & 610 & 1013 \\
\hline Total HH's Home & 286 & 245 & 337 & 209 & 304 \\
\hline$\%$ of HH's Donating & $21.3 \%$ & $22.0 \%$ & $29.9 \%$ & $36.8 \%$ & $26.3 \%$ \\
\hline Average Donation & $\$ 1.90$ & $\$ 1.73$ & $\$ 1.98$ & $\$ 4.48$ & $\$ 2.47$ \\
\hline Avg. Conditional Donation & $\$ 8.92$ & $\$ 7.86$ & $\$ 6.62$ & $\$ 12.15$ & $\$ 9.39$ \\
\hline$\%$ of Donors that Refuse Gift &. & $20.4 \%$ & $9.9 \%$ & $15.6 \%$ & $11.3 \%$ \\
\hline \multicolumn{6}{|l|}{ No Price Point Data Only } \\
\hline HH's Approached & . & . & 634 & . & 481 \\
\hline Total HH's Home & . & . & 199 & . & 143 \\
\hline$\%$ of HH's Donating & . & . & $25.1 \%$ & . & $32.2 \%$ \\
\hline Average Donation & . & . & $\$ 1.98$ & . & $\$ 2.28$ \\
\hline Avg. Conditional Donation & . & . & $\$ 7.88$ & . & $\$ 7.08$ \\
\hline$\%$ of Donors that Refuse Gift & . & . & $18.0 \%$ & . & $19.6 \%$ \\
\hline \multicolumn{6}{|l|}{ Price Point Data Only } \\
\hline HH's Approached & . & . & 380 & . & 532 \\
\hline Total HH's Home & . & . & 138 & . & 161 \\
\hline$\%$ of HH's Donating & . & . & $36.9 \%$ & . & $21.1 \%$ \\
\hline Average Donation & . & . & $\$ 1.98$ & . & $\$ 2.64$ \\
\hline Avg. Conditional Donation & . & . & $\$ 5.37$ & . & $\$ 12.51$ \\
\hline$\%$ of Donors that Refuse Gift & . & . & $1.9 \%$ & 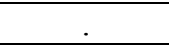 & $0.0 \%$ \\
\hline \multicolumn{6}{|l|}{ Solicitor Characteristics } \\
\hline Total Number of Solicitors & 19 & 16 & 20 & 13 & 16 \\
\hline$\%$ of White Male Solicitors & $10.5 \%$ & $18.75 \%$ & $10 \%$ & $15.4 \%$ & $6.25 \%$ \\
\hline$\%$ of White Female Solicitors & $42.1 \%$ & $18.75 \%$ & $55 \%$ & $30.8 \%$ & $43.75 \%$ \\
\hline$\%$ of Minority Male Solicitors & $21.1 \%$ & $31.25 \%$ & $20 \%$ & $30.8 \%$ & $25 \%$ \\
\hline$\%$ of Minority Female Solicitors & $26.3 \%$ & $31.25 \%$ & $15 \%$ & $23 \%$ & $25 \%$ \\
\hline \multicolumn{6}{|l|}{ No Price Point Data Only } \\
\hline Total Number of Solicitors & . & . & 11 & . & 7 \\
\hline$\%$ of White Male Solicitors & . & . & $9.1 \%$ & & $0.0 \%$ \\
\hline$\%$ of White Female Solicitors & . & . & $45.5 \%$ & & $42.9 \%$ \\
\hline$\%$ of Minority Male Solicitors & . & . & $27.2 \%$ & & $42.9 \%$ \\
\hline$\%$ of Minority Female Solicitors & 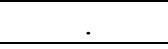 & . & $18.2 \%$ & & $14.3 \%$ \\
\hline \multicolumn{6}{|l|}{ Price Point Data Only } \\
\hline Total Number of Solicitors & . & . & 10 & . & 11 \\
\hline$\%$ of White Male Solicitors & . & . & $10 \%$ & . & $9.1 \%$ \\
\hline$\%$ of White Female Solicitors & . & . & $70 \%$ & & $45.4 \%$ \\
\hline$\%$ of Minority Male Solicitors & . & - & $10 \%$ & . & $18.2 \%$ \\
\hline$\%$ of Minority Female Solicitors & . & . & $10 \%$ & . & $27.3 \%$ \\
\hline \multicolumn{6}{|l|}{ Household Characteristics } \\
\hline$\%$ of White Males & $45.4 \%$ & $40.7 \%$ & $45.1 \%$ & $40.7 \%$ & $40.8 \%$ \\
\hline$\%$ of White Females & $51.0 \%$ & $48.9 \%$ & $42.4 \%$ & $45.9 \%$ & $48.7 \%$ \\
\hline$\%$ of Minority Males & $2.4 \%$ & $4.6 \%$ & $4.2 \%$ & $5.7 \%$ & $5.9 \%$ \\
\hline$\%$ of Minority Females & $1.0 \%$ & $5.8 \%$ & $8.3 \%$ & $7.6 \%$ & $4.6 \%$ \\
\hline Estimated Average Age & 44.1 & 45.0 & 43.5 & 42.9 & 41.0 \\
\hline
\end{tabular}




\begin{tabular}{|r|c|c|c|c|c|}
\hline Public Good Provision & & & & & \\
\hline Total Donations (All Data) & $\$ 541.35$ & $\$ 440.00$ & $\$ 651.43$ & $\$ 953.76$ & $\$ 746.00$ \\
\hline Number of Gifts Distributed &. & 177 & 91 & 114 & 48 \\
\hline \% of HH's that Refuse Gift &. & $27.8 \%$ & $9.9 \%$ & $45.5 \%$ & $11.3 \%$ \\
\hline \% of Donors that Refuse Gift &. & $20.4 \%$ & $9.9 \%$ & $15.6 \%$ & $11.3 \%$ \\
\hline \% of Non-Donors that Refuse &. & $29.8 \%$ &. & $62.8 \%$ &. \\
\hline Expenditure on Gifts &. & $\$ 17.70$ & $\$ 9.10$ & $\$ 1479.72$ & $\$ 623.04$ \\
\hline Net Contribution per HH & $\$ 1.90$ & $\$ 1.72$ & $\$ 1.91$ & $-\$ 2.52$ & $\$ 0.40$ \\
\hline Price Point Data Only & & & & & \\
\hline Total Donations &. &. & $\$ 274.20$ &. & $\$ 425.00$ \\
\hline Number of Gifts Distributed &. &. & 50 &. & 11 \\
\hline Expenditure of Gifts &. &. & $\$ 5.00$ &. & $\$ 142.78$ \\
\hline Net Contribution per HH &. &. & $\$ 1.95$ &. & $\$ 1.75$ \\
\hline No Price Point Data Only & & & & & \\
\hline Total Donations &. &. & $\$ 373.23$ &. & $\$ 321.00$ \\
\hline Number of Gifts Distributed &. &. & 41 &. & 37 \\
\hline Expenditure of Gifts &. &. & $\$ 4.10$ &. & $\$ 480.26$ \\
\hline Net Contribution per HH &. &. & $\$ 1.85$ &. & $-\$ 1.11$ \\
\hline
\end{tabular}

Note: Figures in the table represent summary statistics across the different treatments.

${ }^{\text {a }}$ There were two solicitors in the USG treatment that worked a single day and were unable to elicit any contributions. If we exclude the 30 households visited by these solicitors the percentage of households contributing in the USG treatment increases to $25.1 \%$ and the average donation per contact increases to $\$ 1.97$. 
Table 3: Average Donation per Household - Fixed Effects Regression Models

\begin{tabular}{|c|c|c|c|}
\hline & $\begin{array}{l}\text { Model A } \\
\text { \$'s Given }\end{array}$ & $\begin{array}{l}\text { Model B } \\
\text { \$'s Given }\end{array}$ & $\begin{array}{l}\text { Model C } \\
\text { \$'s Given }\end{array}$ \\
\hline Baseline & $\begin{array}{l}1.74 * * \\
(0.42)\end{array}$ & $\begin{array}{l}1.87 * * \\
(0.44)\end{array}$ & $\begin{array}{l}2.18^{* *} \\
(0.45)\end{array}$ \\
\hline USG Treatment & $\begin{array}{c}0.06 \\
(0.68)\end{array}$ & $\begin{array}{l}-0.07 \\
(0.68)\end{array}$ & $\begin{array}{l}-0.02 \\
(0.68)\end{array}$ \\
\hline ULG Treatment & $\begin{array}{l}2.66^{* *} \\
(0.66)\end{array}$ & $\begin{array}{r}2.58 * * \\
(0.66)\end{array}$ & $\begin{array}{l}2.54 * * \\
(0.66)\end{array}$ \\
\hline CSG Treatment & $\begin{array}{c}0.82 \\
(0.80)\end{array}$ & $\begin{array}{c}0.76 \\
(0.80)\end{array}$ & $\begin{array}{c}0.83 \\
(0.80)\end{array}$ \\
\hline CLG Treatment & $\begin{array}{r}1.02 \\
(0.77) \\
\end{array}$ & $\begin{array}{c}0.99 \\
(0.77) \\
\end{array}$ & $\begin{array}{c}1.07 \\
(0.77)\end{array}$ \\
\hline CSG - Min Treatment & $\begin{array}{l}-0.42 \\
(0.74)\end{array}$ & $\begin{array}{l}-0.49 \\
(0.73)\end{array}$ & $\begin{array}{l}-0.53 \\
(0.73)\end{array}$ \\
\hline CLG - Min Treatment & $\begin{array}{c}0.60 \\
(0.74) \\
\end{array}$ & $\begin{array}{c}0.74 \\
(0.74) \\
\end{array}$ & $\begin{array}{c}0.71 \\
(0.74) \\
\end{array}$ \\
\hline HH Visited Prior & & $\begin{array}{c}-0.92 * * \\
(0.44) \\
\end{array}$ & $\begin{array}{c}-0.93 * * \\
(0.44) \\
\end{array}$ \\
\hline Warm List HH & & $\begin{array}{l}1.52 * * \\
(0.61)\end{array}$ & $\begin{array}{l}1.51 * * \\
(0.61)\end{array}$ \\
\hline HH Age 30 or Under & & & $\begin{array}{c}-1.10^{* *} \\
(0.55) \\
\end{array}$ \\
\hline HH Age 65 or Over & & & $\begin{array}{c}-0.93 * * \\
(0.42)\end{array}$ \\
\hline Fixed Effects & $\begin{array}{c}\text { Yes }- \\
36 \text { Solicitors }\end{array}$ & $\begin{array}{c}\text { Yes - } \\
36 \text { Solicitors }\end{array}$ & $\begin{array}{c}\text { Yes }- \\
36 \text { Solicitors }\end{array}$ \\
\hline Observations & 1381 & 1381 & 1381 \\
\hline R-Squared & 0.02 & 0.02 & 0.03 \\
\hline
\end{tabular}

** Denotes statistical significance at the $\mathrm{p}<0.05$ level

Note: Cell entries provide parameter estimates for a fixed effects linear regression model of contribution levels (including the zeroes) for our experiment. Cell entries can be read as follows - average contribution levels in the ULG treatment (column 1, row 4) are approximately \$2.66 greater than those for our baseline VCM treatment. 
Table 4: Probability of Contributing - Fixed Effects Regression Model

\begin{tabular}{|c|c|c|c|}
\hline & $\begin{array}{l}\text { Model A } \\
\text { Pr (Give) }\end{array}$ & $\begin{array}{l}\text { Model B } \\
\text { Pr (Give) }\end{array}$ & $\begin{array}{l}\text { Model C } \\
\text { Pr (Give) }\end{array}$ \\
\hline Baseline & $\begin{array}{c}0.14 * * \\
(0.03)\end{array}$ & $\begin{array}{c}0.15^{* *} \\
(0.03)\end{array}$ & $\begin{array}{l}0.16^{* *} \\
(0.03)\end{array}$ \\
\hline USG Treatment & $\begin{array}{l}0.10^{* *} \\
(0.05)\end{array}$ & $\begin{array}{l}0.09^{*} \\
(0.05)\end{array}$ & $\begin{array}{l}0.09^{*} \\
(0.05)\end{array}$ \\
\hline ULG Treatment & $\begin{array}{c}0.23^{* *} \\
(0.05)\end{array}$ & $\begin{array}{c}0.22^{* *} \\
(0.05)\end{array}$ & $\begin{array}{c}0.22^{* *} \\
(0.05)\end{array}$ \\
\hline CSG Treatment & $\begin{array}{c}0.17 * * \\
(0.06)\end{array}$ & $\begin{array}{l}0.16^{* *} \\
(0.06)\end{array}$ & $\begin{array}{l}0.16^{* *} \\
(0.06)\end{array}$ \\
\hline CLG Treatment & $\begin{array}{c}0.21^{* *} \\
(0.05)\end{array}$ & $\begin{array}{c}0.20^{* *} \\
(0.05)\end{array}$ & $\begin{array}{c}0.21^{* *} \\
(0.05)\end{array}$ \\
\hline CSG - Min Treatment & $\begin{array}{c}0.21^{* *} \\
(0.05)\end{array}$ & $\begin{array}{c}0.21^{* *} \\
(0.05)\end{array}$ & $\begin{array}{l}0.20^{* *} \\
(0.05)\end{array}$ \\
\hline CLG - Min Treatment & $\begin{array}{c}0.05 \\
(0.05)\end{array}$ & $\begin{array}{c}0.06 \\
(0.05)\end{array}$ & $\begin{array}{c}0.06 \\
(0.05)\end{array}$ \\
\hline HH Visited Prior & & $\begin{array}{c}-0.07 * * \\
(0.03)\end{array}$ & $\begin{array}{c}-0.07^{* *} \\
(0.03)\end{array}$ \\
\hline Warm List HH & & $\begin{array}{l}0.14^{* *} \\
(0.04)\end{array}$ & $\begin{array}{l}0.14^{* *} \\
(0.04)\end{array}$ \\
\hline HH Age 30 or Under & & & $\begin{array}{l}-0.03 \\
(0.04)\end{array}$ \\
\hline HH Age 65 or Over & & & $\begin{array}{l}-0.04 \\
(0.03)\end{array}$ \\
\hline Fixed Effects & $\begin{array}{c}\text { Yes - } \\
\text { 36 Solicitors }\end{array}$ & $\begin{array}{c}\text { Yes - } \\
\text { 36 Solicitors }\end{array}$ & $\begin{array}{c}\text { Yes - } \\
\text { 36 Solicitors }\end{array}$ \\
\hline Observations & 1381 & 1381 & 1381 \\
\hline R-Squared & 0.02 & 0.02 & 0.03 \\
\hline
\end{tabular}

$* *$ Denotes statistical significance at the $\mathrm{p}<0.05$ level

$*$ Denotes statistical significance at the $\mathrm{p}<0.10$ level

Note: Cell entries provide parameter estimates for an fixed effects model estimating the dichotomous decision of whether or not a household made a contribution to the Hazard Center. Cell entries can be read as follows - agents in the ULG treatment (column 1, row 4) are 23 percent more likely on average to contribute to the Hazard Center than in the VCM. 
Table 5: Design - Experiment II

\begin{tabular}{|c|c|c|c|}
\hline & $\begin{array}{c}\text { Morning } \\
\text { Solicitation }\end{array}$ & $\begin{array}{l}\text { Afternoon } \\
\text { Solicitation }\end{array}$ & $\begin{array}{c}\text { Evening } \\
\text { Solicitation }\end{array}$ \\
\hline $\begin{array}{l}\text { Saturday } \\
\text { June } 12^{\text {th }}\end{array}$ & $\begin{array}{l}16 \text { Solicitors } \\
670 \text { Visits } \\
245 \text { Home }\end{array}$ & $\begin{array}{l}16 \text { Solicitors } \\
696 \text { Visits } \\
266 \text { Home }\end{array}$ & \\
\hline $\begin{array}{l}\text { Sunday } \\
\text { June } 13^{\text {th }}\end{array}$ & & $\begin{array}{c}32 \text { Solicitors } \\
1289 \text { Visits } \\
494 \text { Home }\end{array}$ & \\
\hline $\begin{array}{l}\text { Tuesday } \\
\text { June } 15^{\text {th }}\end{array}$ & & & $\begin{array}{c}2 \text { Solicitors } \\
34 \text { Visits } \\
18 \text { Home }\end{array}$ \\
\hline $\begin{array}{l}\text { Wednesday } \\
\text { June } 16^{\text {th }}\end{array}$ & & & $\begin{array}{c}5 \text { Solicitors } \\
83 \text { Visits } \\
51 \text { Home }\end{array}$ \\
\hline
\end{tabular}


Table 6: Summary Statistics - Experiment II

\begin{tabular}{|c|c|c|c|c|}
\hline & $\begin{array}{c}\text { VCM in } \\
\text { Experiment I }\end{array}$ & $\begin{array}{c}\text { ULG in } \\
\text { Experiment I }\end{array}$ & $\begin{array}{c}\text { CLG in } \\
\text { Experiment I }\end{array}$ & $\begin{array}{l}\text { Not Solicited in } \\
\text { Experiment I }\end{array}$ \\
\hline \multicolumn{5}{|l|}{ All Data Pooled } \\
\hline Total HH's Home & 62 & 65 & 114 & 833 \\
\hline$\%$ of HH's Donating & $22.6 \%$ & $12.3 \%$ & $18.4 \%$ & $21.2 \%$ \\
\hline Average Donation & $\begin{array}{l}\$ 1.66 \\
(4.56)\end{array}$ & $\begin{array}{l}\$ 1.06 \\
(4.06)\end{array}$ & $\begin{array}{l}\$ 1.84 \\
(5.30)\end{array}$ & $\begin{array}{l}\$ 1.84 \\
(5.22)\end{array}$ \\
\hline $\begin{array}{r}\text { Average Conditional } \\
\text { Donation }\end{array}$ & $\begin{array}{l}\$ 7.36 \\
(7.24)\end{array}$ & $\begin{array}{l}\$ 8.63 \\
(8.73) \\
\end{array}$ & $\begin{array}{l}\$ 10.00 \\
(8.56)\end{array}$ & $\begin{array}{l}\$ 8.68 \\
(8.34)\end{array}$ \\
\hline \multicolumn{5}{|l|}{ Previous Givers Only } \\
\hline Total HH's Home & 35 & 28 & 39 & \\
\hline$\%$ of HH's Donating & $28.6 \%$ & $14.3 \%$ & $35.9 \%$ & \\
\hline Average Donation & $\begin{array}{l}\$ 1.83 \\
(4.80) \\
\end{array}$ & $\begin{array}{l}\$ 1.29 \\
(4.81)\end{array}$ & $\begin{array}{l}\$ 3.49 \\
(6.65) \\
\end{array}$ & \\
\hline $\begin{array}{r}\text { Average Conditional } \\
\text { Donation }\end{array}$ & $\begin{array}{l}\$ 6.40 \\
(7.38)\end{array}$ & $\begin{array}{l}\$ 9.00 \\
(10.74)\end{array}$ & $\begin{array}{l}\$ 9.71 \\
(8.02)\end{array}$ & \\
\hline Average Prior Donation & $\begin{array}{l}\$ 8.49 \\
(7.64) \\
\end{array}$ & $\begin{array}{l}\$ 11.86 \\
(8.14)\end{array}$ & $\begin{array}{l}\$ 10.13 \\
(9.05)\end{array}$ & \\
\hline \multicolumn{5}{|l|}{ Previous Non-Givers } \\
\hline Total HH's Home & 27 & 37 & 75 & \\
\hline$\%$ of HH's Donating & $14.8 \%$ & $10.8 \%$ & $9.33 \%$ & \\
\hline Average Donation & $\begin{array}{l}\$ 1.44 \\
(4.32) \\
\end{array}$ & $\begin{array}{l}\$ 0.89 \\
(3.45)\end{array}$ & $\begin{array}{l}\$ 0.99 \\
(4.25)\end{array}$ & \\
\hline $\begin{array}{r}\text { Average Conditional } \\
\text { Donation } \\
\end{array}$ & $\begin{array}{l}\$ 9.75 \\
(7.32) \\
\end{array}$ & $\begin{array}{l}\$ 8.25 \\
(7.89) \\
\end{array}$ & $\begin{array}{l}\$ 10.57 \\
(10.21) \\
\end{array}$ & \\
\hline \multicolumn{5}{|l|}{ Household Characteristics } \\
\hline$\%$ of White Males & $45.2 \%$ & $46.2 \%$ & $44.7 \%$ & $45.3 \%$ \\
\hline$\%$ of White Females & $48.4 \%$ & $38.5 \%$ & $45.6 \%$ & $40.5 \%$ \\
\hline$\%$ of Minority Males & $1.6 \%$ & $4.6 \%$ & $5.3 \%$ & $5.2 \%$ \\
\hline$\%$ of Minority Females & $3.2 \%$ & $9.2 \%$ & $4.4 \%$ & $7.1 \%$ \\
\hline Estimated Average Age & 49 & 42.9 & 40 & 44.6 \\
\hline
\end{tabular}


Table 7: Average Donation per Household - Fixed Effects Regression Models

\begin{tabular}{|c|c|c|c|}
\hline & Model A & Model B & Model C \\
\hline Constant & $\begin{array}{l}1.81 * * \\
(0.18)\end{array}$ & $\begin{array}{l}2.00 * * \\
(0.22)\end{array}$ & $\begin{array}{l}0.95 * * \\
(0.34)\end{array}$ \\
\hline Prior Donor from a VCM & $\begin{array}{l}-0.34 \\
(1.42)\end{array}$ & $\begin{array}{l}-0.26 \\
(1.42)\end{array}$ & $\begin{array}{l}-0.30 \\
(1.41)\end{array}$ \\
\hline $\begin{array}{l}\text { Prior Donor from Unconditional } \\
\text { Gift Treatment }\end{array}$ & $\begin{array}{l}-0.12 \\
(1.35)\end{array}$ & $\begin{array}{l}-0.19 \\
(1.35)\end{array}$ & $\begin{array}{l}-0.25 \\
(1.34)\end{array}$ \\
\hline $\begin{array}{l}\text { Prior Donor from Conditional } \\
\text { Gift Treatment }\end{array}$ & $\begin{array}{l}2.12 * * \\
(1.03)\end{array}$ & $\begin{array}{l}2.18 * * \\
(1.03)\end{array}$ & $\begin{array}{l}1.96^{*} \\
(1.03)\end{array}$ \\
\hline Prior Non-Donor from a VCM & $\begin{array}{l}-0.25 \\
(1.09)\end{array}$ & $\begin{array}{l}-0.30 \\
(1.09)\end{array}$ & $\begin{array}{l}-0.31 \\
(1.08)\end{array}$ \\
\hline $\begin{array}{l}\text { Prior Non-Donor from an } \\
\text { Unconditional Gift Treatment }\end{array}$ & $\begin{array}{l}-0.47 \\
(0.91)\end{array}$ & $\begin{array}{l}-0.44 \\
(0.91)\end{array}$ & $\begin{array}{l}-0.31 \\
(0.90)\end{array}$ \\
\hline $\begin{array}{l}\text { Prior Non-Donor from a } \\
\text { Conditional Gift Treatment }\end{array}$ & $\begin{array}{l}-0.43 \\
(0.73)\end{array}$ & $\begin{array}{l}-0.38 \\
(0.72)\end{array}$ & $\begin{array}{l}-0.31 \\
(0.72)\end{array}$ \\
\hline Solicitee Age 30 or Under & & $\begin{array}{l}-0.78^{*} \\
(0.41)\end{array}$ & $\begin{array}{l}-0.72 * \\
(0.41)\end{array}$ \\
\hline Solicitee Age 65 or Above & & $\begin{array}{l}-0.07 \\
(0.51)\end{array}$ & $\begin{array}{l}-0.12 \\
(0.50)\end{array}$ \\
\hline White Male Solicitee & & & $\begin{array}{l}0.94 * * \\
(0.19)\end{array}$ \\
\hline White Female Solicitee & & & $\begin{array}{l}1.16^{* *} \\
(0.39)\end{array}$ \\
\hline Minority Female Solicitee & & & $\begin{array}{l}1.19 * \\
(0.69)\end{array}$ \\
\hline Solicitor Fixed Effects & Yes & Yes & Yes \\
\hline \# of Observations & 1074 & 1074 & 1074 \\
\hline R-Squared & 0.01 & 0.01 & 0.04 \\
\hline
\end{tabular}


Table 8: Participation Rates - Fixed Effects Regression Models

\begin{tabular}{|c|c|c|c|}
\hline & Model A & Model B & Model C \\
\hline Constant & $\begin{array}{c}0.21^{* *} \\
(0.01)\end{array}$ & $\begin{array}{l}0.23 * * \\
(0.02)\end{array}$ & $\begin{array}{c}0.17^{* *} \\
(0.03)\end{array}$ \\
\hline Prior Donor from a VCM & $\begin{array}{c}0.01 \\
(0.11)\end{array}$ & $\begin{array}{c}0.02 \\
(0.11)\end{array}$ & $\begin{array}{c}0.01 \\
(0.11)\end{array}$ \\
\hline $\begin{array}{l}\text { Prior Donor from Unconditional } \\
\text { Gift Treatment }\end{array}$ & $\begin{array}{l}-0.07 \\
(0.10)\end{array}$ & $\begin{array}{l}-0.07 \\
(0.10)\end{array}$ & $\begin{array}{l}-0.06 \\
(0.10)\end{array}$ \\
\hline $\begin{array}{l}\text { Prior Donor from Conditional } \\
\text { Gift Treatment }\end{array}$ & $\begin{array}{l}0.25 * * \\
(0.08)\end{array}$ & $\begin{array}{l}0.25^{* *} \\
(0.08)\end{array}$ & $\begin{array}{l}0.24 * * \\
(0.08)\end{array}$ \\
\hline Prior Non-Donor from a VCM & $\begin{array}{l}-0.04 \\
(0.08)\end{array}$ & $\begin{array}{l}-0.04 \\
(0.08)\end{array}$ & $\begin{array}{l}-0.04 \\
(0.08)\end{array}$ \\
\hline $\begin{array}{l}\text { Prior Non-Donor from an } \\
\text { Unconditional Gift Treatment }\end{array}$ & $\begin{array}{l}-0.06 \\
(0.07)\end{array}$ & $\begin{array}{l}-0.06 \\
(0.07)\end{array}$ & $\begin{array}{l}-0.05 \\
(0.07)\end{array}$ \\
\hline $\begin{array}{l}\text { Prior Non-Donor from a } \\
\text { Conditional Gift Treatment }\end{array}$ & $\begin{array}{l}-0.07 \\
(0.06)\end{array}$ & $\begin{array}{l}-0.07 \\
(0.06)\end{array}$ & $\begin{array}{l}-0.07 \\
(0.06) \\
\end{array}$ \\
\hline Solicitee Age 30 or Under & & $\begin{array}{l}-0.05 \\
(0.03)\end{array}$ & $\begin{array}{l}-0.04 \\
(0.03)\end{array}$ \\
\hline Solicitee Age 65 or Above & & $\begin{array}{l}-0.03 \\
(0.04)\end{array}$ & $\begin{array}{l}-0.04 \\
(0.04)\end{array}$ \\
\hline White Male Solicitee & & & $\begin{array}{l}0.04 * * \\
(0.02)\end{array}$ \\
\hline White Female Solicitee & & & $\begin{array}{c}0.07 * * \\
(0.03)\end{array}$ \\
\hline Minority Female Solicitee & & & $\begin{array}{l}0.12 * * \\
(0.05)\end{array}$ \\
\hline Solicitor Fixed Effects & Yes & Yes & Yes \\
\hline \# of Observations & 1074 & 1074 & 1074 \\
\hline R-Squared & 0.01 & 0.01 & 0.02 \\
\hline
\end{tabular}


Figure 1: The Frequency of Donations - Small Gift Treatments

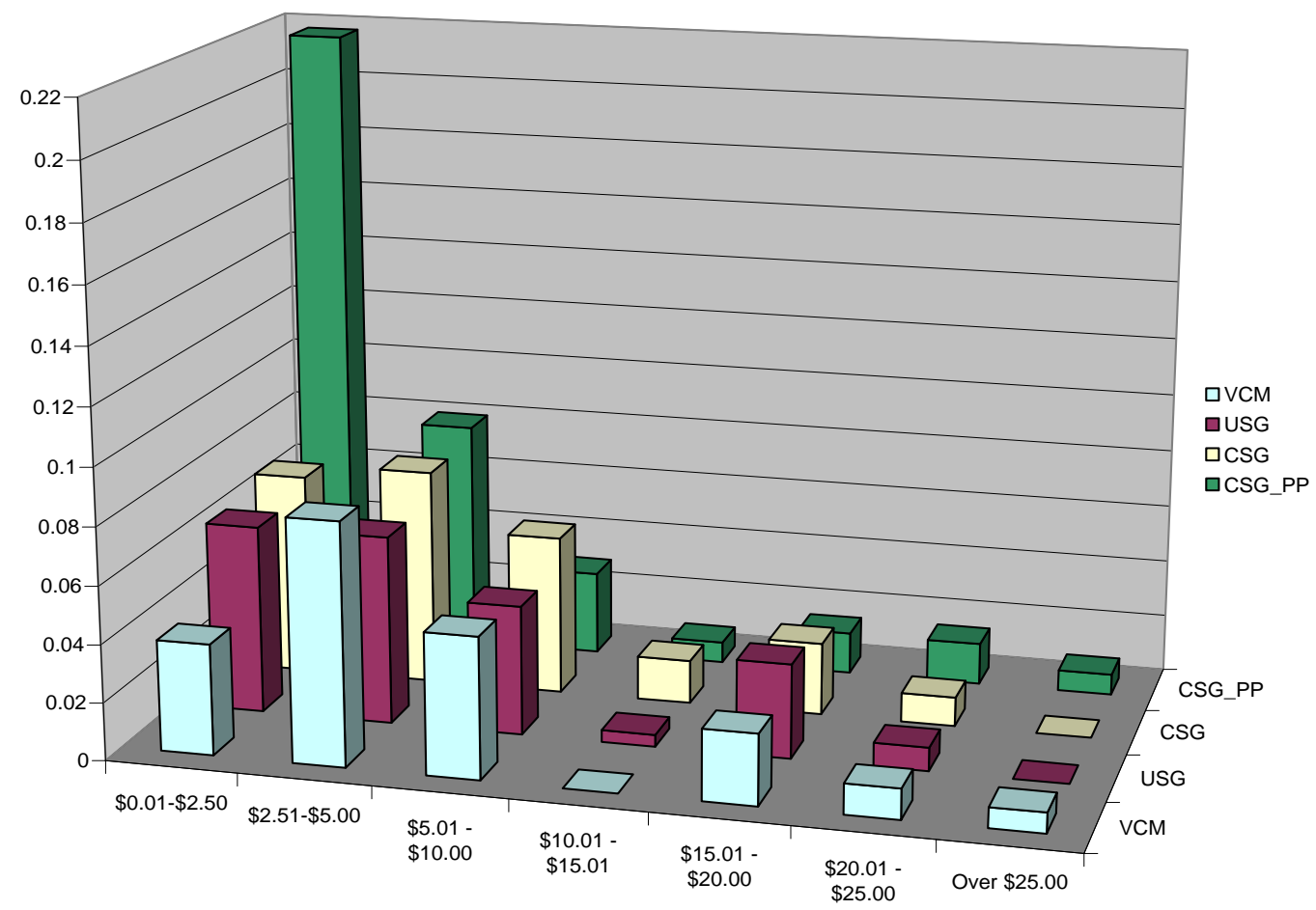

Figure 2: The Frequency of Donations - Large Gift Treatments

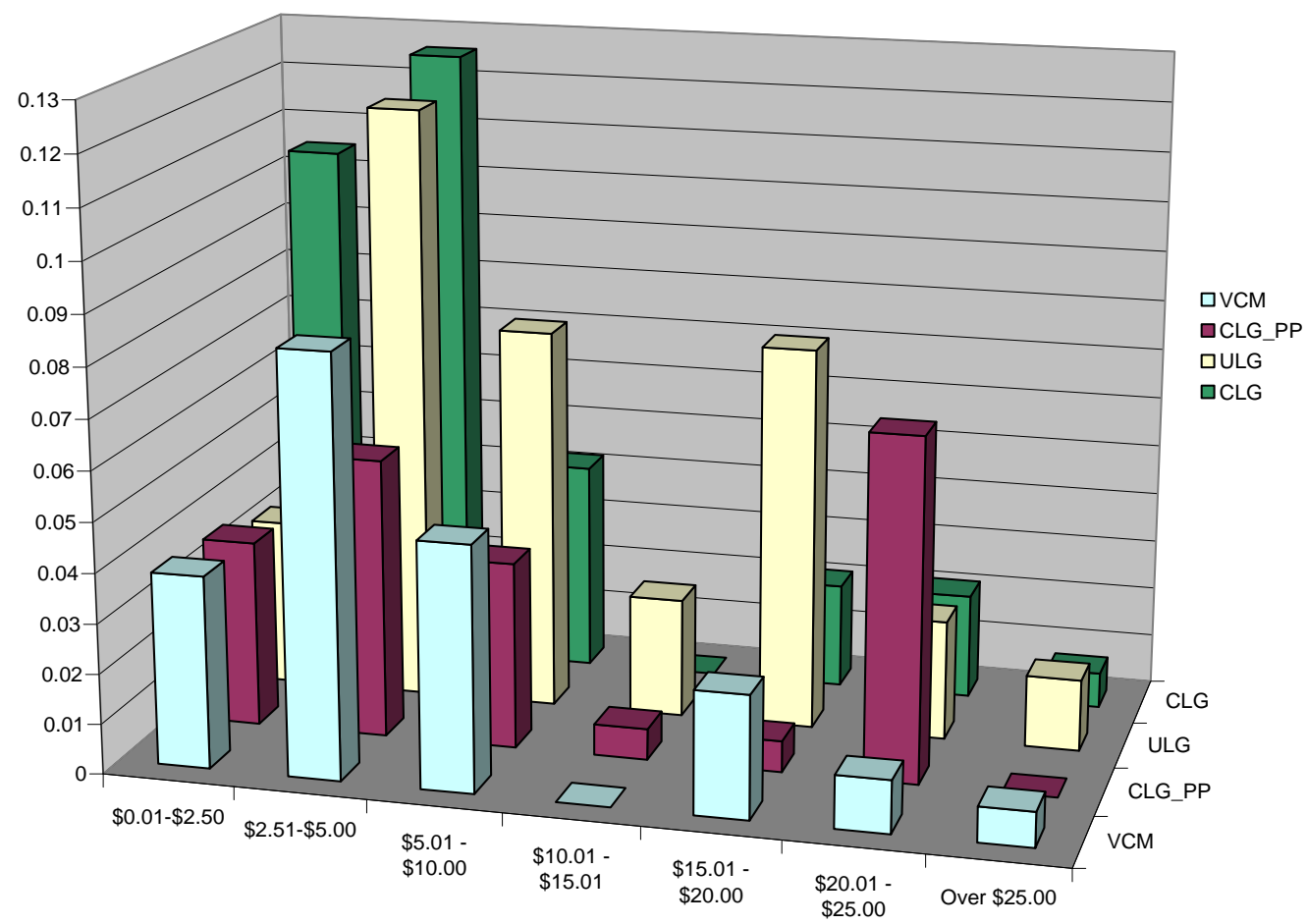




\section{$\underline{\text { Appendix - Solicitation Scripts and Informational Brochure }}$}

\section{ECU Center for Natural Hazards Research - Baseline Script}

(If a minor answers the door, please ask to speak to a parent. Never enter a house.)

- Hi, my name is _. I am an ECU student visiting Pitt County households today on behalf of the ECU Center for Natural Hazards Research.

(Hand the person at the door a copy of our newsletter.)

- The Hazard Center provides support and coordination for research on natural hazard risks, such as hurricanes, tornadoes, and flooding.

- Our newsletter describes recent research initiatives in the wake of Hurricane Katrina, and the Center's mission.

- The primary goal of the center is to reduce the loss of life and property damages due to severe weather events.

- We are collecting contributions today on behalf of the ECU Hazards Center.

- The Center is a non-profit organization and these funds will be used to conduct research that benefits Pitt County and the surrounding area.

- Would you like to make a contribution today?

(If you receive a contribution, please write a receipt that includes their name and contribution amount. If the resident asks, contributions are tax deductible).

- If you have questions regarding the Center or want additional information, visit the web site listed in the newsletter.

Thank you. 


\section{ECU Center for Natural Hazards Research- Informational Brochure}

\section{Center for Natural Hazards Research}

East Carolina University. Thomas Harriot College of Arts and Sciences

\section{Who We Are}

The Center for Natural Hazards Research (CNHR) at East Carolina University, founded in 2004 , focuses on hurricane, tornado, flooding, and erosion hazards as they affect eastern North Carolina and the United States. The CNHR brings together researchers from various institutions and disciplines to identify methods to reduce potential losses of life, property, and infrastructuse ducing weather emergencies and to provide support and coordination for research and outreach on natucal hazard risks.

Our areas of active research include the financial impacts of huericanes and floods, the effectiveness of warning systems, how policy-makers should handle evacuations, and how households can protect themselves from natual hazards. The CNHR received grants from the National Science Foundation in January to study the effects of Hurricane Katrina on the gulf region and to investigate reconstruction efforts in New Orleans.

Like you, we have watched the terrible aftermath of natucal disasters in the United States and overseas over the past several months. Only minutes after the wave struck, news bulletins arrived to tell us of the horror and loss of life caused by the Indian Ocean Tsunnami on December 26, 2004. Victims of that disaster had virtually no warning of the killes wave. The tropical depression that became Hurricane Katrina, on the other hand, was tracked for more than six days before it made landfall on the Louisiana/Mississippi border. Scenarios projecting a major hurricane making landfall near New Orleans have been studied for the last twenty years! Yet, we watched in disbelief as news commentators showed us the destruction, suffering, and death that resulted from Katrina's waves, wind, and rain. Many of us wondered how this could happen in the United States of America. If we can help other countries and their people when a natural disaster strikes, how is it that we are unable to take care of ous own' Katrina overwhelmed us, demonstrating the inadequacy of evacuation plans and emergency response communication networks. Relief efforts were painfully slow: Surely we can do better than this!

The CNHR plans to be part of the solution by engaging in high quality academic research and outreach that includes disseminating our research findings in a usable form to the community, not just to other researchers and academics. Ons website will provide information about natural hazards that is useful to people in eastern North Carolina. We would like to know what kinds of information on natural hazards you would find most valuable, so please visit us at wrwwecu.edu/hazards to fill out our online feedback form

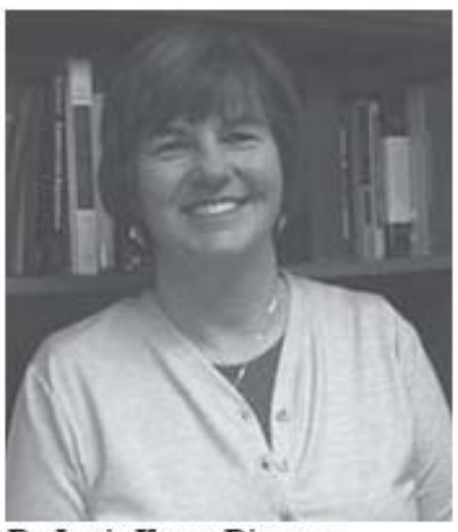

Dr. Jamie Kruse, Director Center for Natural Hazards Research East Carolina University

\section{Tell Us What You Think!}

The Center for Natural

Hazards Research at East

Carolina University plans to

undertake projects that focus

on natural hazards in Pitt

County, and we would like to

know what types of projects

you think are needed.

Please visit our website at

www.ecu.edu/hazards to tell

us your project ideas. To sub-

mit your ideas, simply click

the red "Feedback" button on

our homepage and fill out the

online form. 


\section{Recent CNHR Projects}

The "New" New Orleans: Evaluating Preferences for Rebuilding Plans after Hurricane Katrina. This grant from the National Science Foundation enables researchers from ECU's Economics, Planning, and Sociology departments to measure national attitudes toward rebuilding New Orleans and the commitment of federal monies to restoration. Researchers will assess what people want to preserve about New Orleans and to what extent citizens are willing to pay for it.

Collecting Economic Impact Data: Implications for Disaster Areas and Host Regions. With this grant from the National Science Foundation, researchers from ECU, Texas Tech University, Southern Mississippi-Long Beach, and Stephen F. Austin College will assess the economic impact of Katrina on the affected areas as well as the impact of evacuees on their host communities. North Carolina and Texas took in thousands of evacuees, and researchers will study whether federal funding available for the evacuees provides a positive economic impact to offset the drain on the host regions' resources.

Spatial, Environmental and Behavioral Determinants of Valuation of Coastal Erosion Risk. This ECU Research Development Grant enables researchers from ECU's Geography and Economics departments uncover risk attitudes and time discounting behavior of coastal property owners. Researchers will explore whether the public has adequately accounted for the inherent risks of these attractive coastal locations in their investment decisions.

\section{ecu logo}

Natural Disasters and Bank Performance. This Federal Deposit Insurance Corporation Center for Financial Research grant enabled researchers from ECU and Texas Tech University to examine the impact of wind damage on small and large banks in several tornado-prone areas and hurricane-prone areas.

Determinants of Economic Recovery in the Aftermath of a Hurricane Disaster. This National Science Foundation grant would enable researchers from ECU and Texas Tech University to examine the dynamic behavior of economic growth in areas affected by major or minor hurricanes in the years 1992 , 1999,2004 , and 2005 .

Perceptions of Coastal Hazards: Decision Making Under Multidimensional Risk. This proposal, submitted to the National Science Foundation, would enable researchers from ECU's Economics and Geography departments to examine the perceptions and behavior of individuals in a natural decision environment that involves multiple risks that include a significant time dimension.

\section{Records of the 2005 Atlantic Hurricane Season}

- 26 Named Storms (previous record: 21 in 1933)

- 13 Hurricanes (previous record: 12 in 1969)

- Four major hurricanes hitting the U.S. (previous record: three in 2004)

- Three Category 5 Hurricanes (previous record: two in 1960 and 1961)

- Seven Tropical Storms before August 1 (previous record: five in 1997)

- Costliest Atlantic Season ( $\$ 107$ billion+) (previous record 2004, $\$ 45$ billion)

- Costliest Hurricane: Katrina ( $\$ 80$ billion+) (previous record Andrew, $\$ 26.5$ billion - 1992 dollars)

- Deadliest U.S. Hurricane since 1928: Katrina (1,300+)

- Strongest Hurricane in the Atlantic Basin: Wilma 882 mbar (previous record: Gilbert at 888 mbar)

- Three of the six strongest hurricanes on record: Wilma 882 mbar $\left(1^{*}\right)$, Rita 897 mbar $\left(4^{\text {th }}\right)$, Katrina 902 mbar $\left(6^{\text {tr }}\right)$

- July hurricane: Emily (155 mph top sustained winds) (previous record: Dennis (150 mph) in 2005; Hurricane \#1 (140 mph) in 1926

Storm record's are from www.weather.com. For more records of the 2005 . Atlantic Harricane Season, wisit ous website at www.ecw.eds/ bagards.

\section{Help to Fund Research Projects in Pitt County!}

The Center for Natural Hazards Research at East Carolina University is launching a fundraising initiative in Pitt County. If you receive a mail or door solicitation from one of our associates, keep in mind that any donations you make will be earmarked for projects in Pitt County only. Thank you! 